\title{
Description of Observations
}

\section{SIGNIFICANCE OF REPORTED OCEANOGRAPHIC DATA}

Routine field measurements of oceanographic parameters by conventional methods are usually subject to at least the following random errors:

$$
\begin{array}{ll}
\text { depth } & \pm 4 \mathrm{~m} \text { (in the upper } 1000 \mathrm{~m} \text { ) } \\
\text { temperature } & \pm 0.02{ }^{\circ} \mathrm{C} \\
\text { salinity } & \pm 0.03 \% \text { (Knudsen titration) } \\
& \pm 0.004 \% \text { (conductivity bridge) } \\
\text { oxygen } & \pm 0.04 \mathrm{ml} / \mathrm{L} \\
\text { phosphate } & \pm 0.05 \text { to } 0.1 \mathrm{\mu g} \text { at } / \mathrm{L}
\end{array}
$$

The precision of measurements of temperature and of Knudsen determinations of salinity made in the field have been analyzed by Wooster and Taft (1958). The above estimate of the precision of measurements of salinity made routinely at sea by conductivity bridge is that of Strickland (1958b).

Interpolated values at standard depths are known with less precision, and the resulting uncertainty in specific volume anomaly and thermosteric anomaly at standard depths due to random errors in field measurements of temperature, salinity and depth is of the order of three centiliters per ton. Therefore, in this publication series it is the practice to report specific volume anomaly and thermosteric anomaly to no more than one part in $10^{5}$ (one cl/ton) and geopotential anomaly to no more than the nearest dynamic centimeter.

It should be noted also that computations of salinity (from measured chlorinity) and density (sigma-t, specific volume anomaly and thermosteric anomaly) reported in this volume have all been based on the empirical equations and tables by Knudsen (1901) and Ekman (1908). Because of the inadequacy of our present knowledge of the equation of state of sea water (Eckart, 1958) and the uncertainty of the relationship between chlorinity and salinity (Carritt and Carpenter, 1959), it is possible that these computed values differ systematically from the absolute values. However, in the upper thousand meters at least, Reid (1959) has shown that the influence of such systematic errors on the accuracy of computed geostrophic flow is significantly smaller than the influence of errors in the determination of temperature, salinity, pressure and position.

\section{NOTES ON PARTICULAR CRUISES}

Cruises TO-59-1 and TO-59-2

The Scripps Tuna Oceanography Research Program (STOR) of the Scripps Institution of Oceanography made two cruises in 1959 which are known as TO-59-1 and TO-59-2. Physical, chemical and biological data from these cruises are listed in Special Scientific Report--Fisheries No. 420 (1962) of the United States Fish and Wildlife Service.
The main purpose of each cruise was to investigate the distribution of ocean properties in the Gulf of Tehuantepec, on the Pacific coast of southern Mexico, as part of a series of comparative observations in that area at different seasons. In addition, each cruise provided an opportunity for gathering information about the interrelationships of light, nutrients, thermal structure and biota in ocean waters along the Pacific coast of Mexico.

Vermilion Sea Expedition

On Vermilion Sea Expedition two research vessels conducted a geological and geophysical exploration of the Gulf of California from February to May. The work was supported by grants from the Office of Naval Research, the Bureau of Ships of the U. S. Navy and the American Petroleum Institute.

Dorado Expedition

SALINITIES: Salinity determinations by Knudsen method on Dorado Expedition were found to be too high by a mean value of $0.05 \%$. This difference was indicated by values as high as $34.76 \%$ reported at depths of 2000 meters or more where salinity is not expected to exceed $34.69 \%$. The Dorado salinity data were compared with the data of other cruises in the same region, especially with STEP-I Expedition (September-December, 1960) where salinity was determined by conductivity bridge. Because there is also considerable variability from station to station, the data are published as originally listed, without correction but with footnotes to indicate variation.

Costa Rica Dome Cruise

The Costa Rica Dome Cruise was conducted jointly by the Inter-American Tropical Tuna Commission and the Scripps Institution. The principal objective was a comprehensive physical, chemical and biological survey of the anticlinal thermal dome centered about 200 miles west of Costa Rica, Central America, at the eastern end of the boundary between the Equatorial Countercurrent and the North Equatorial Current. A secondary objective was a similar but less extensive survey of the waters within fifteen miles of Cocos Island.

\section{MV $\underline{\text { Pioneer }}$ and MV $\underline{\text { Tordenskjold }}$}

The purpose of the hydrographic observations made by these two vessels on Cruises Ocean-1 and Ocean-2 from May to September was to permit investigation of relationships between physical, chemical and biological conditions and the abundance and distribution of salmon stocks, as determined by gill-net catches. Data were also collected by MV Tordenskjold in Bristol Bay of the Bering Sea for the King Crab Investigations.

The interpolations of values at standard depths were performed by the IBM Type 650 Magnetic-Drum DataProcessing machine in the Research Computer Laboratory of the University of Washington, using the three-point Lagrange curve based upon one point above and two points below the desired depth. 
Cruises P-59-1 through P-59-4, NP-59-2, NP-59-3 and CS-59-3

The interpolations for values at standard depths and the determination of calculated depths were carried out on the ALWAC III-E digital computer at the computing center of the University of British Columbia. Interpolations were made by the two-point logarithmic method described by Fofonoff and Tabata (1958).

Cruise P-59-5

The interpolations for values at standard depths and the determination of calculated depths were carried out on the ALWAC III-E digital computer at the computing center of the University of British Columbia. Interpolations were made by the three-point parabolic method described by Froese (1960).

Cruise NP-59-1

The interpolations for values at standard depths and the determination of calculated depths were carried out on the ALWAC II-E digital computer at the computing center of the University of British Columbia. Interpolations were made by the three-point parabolic method described by Fofonoff and Froese (1958).

USCGSS Explorer and USS $\underline{\text { Staten Island }}$

The interpolations for values at standard depths and determination of calculated depths were carried out by machine programs at the U.S. Naval Oceanographic Office, Washington, D.C. Interpolations were made by the three-point Lagrange method (U.S.N. Hydrogr . Off., 1960; Nat Oceanogr. Data Center, 1962).

Cruises BB-234 and BB-235

Interpolation of values at standard depths was performed by the IBM Type 650 Magnetic-Drum DataProcessing Machine in the Research Computer Laboratory of the University of Washington, using the three-point Lagrange curve based upon one point above and two points below the desired depth. Corrections were made for any peculiar interpolations which resulted from use of this method in the upper layers. 


\begin{tabular}{|c|c|c|c|c|c|c|c|c|c|}
\hline Cruise & Vessel & $\begin{array}{l}\text { Dates of } \\
\text { hydro casts }\end{array}$ & $\begin{array}{r}\mathrm{Nu} \\
0-500 \mathrm{~m}\end{array}$ & $\begin{array}{l}\text { aber and dept } \\
500-1000 \mathrm{~m}\end{array}$ & $\begin{array}{l}\text { hs of hydrograp } \\
1000-2000 \mathrm{~m}\end{array}$ & $\begin{array}{l}\text { hic statior } \\
>2000 \mathrm{~m}\end{array}$ & Total & $\begin{array}{l}\mathrm{T} \text { and Sobs } \\
\text { at } 10 \mathrm{~m}\end{array}$ & $\begin{array}{l}\text { No. of } \\
\text { BT obs }\end{array}$ \\
\hline \multirow[t]{2}{*}{5901} & Black Douglas $^{\mathrm{a}}$ & $16-30 \mathrm{i}$ & 18 & 32 & 0 & 0 & 50 & 9 & $97^{\mathrm{b}}$ \\
\hline & Spencer F. Baird & $7-27 \mathrm{i}$ & 32 & 73 & 0 & 0 & 105 & 35 & $216^{\mathrm{b}}$ \\
\hline \multirow{2}{*}{5902} & Paolina-T & $7-14$ ii & 0 & 6 & 0 & 0 & 6 & 33 & $61^{b}$ \\
\hline & Black Douglas & $12-25$ ii & 4 & 8 & 0 & 0 & 12 & 67 & $140^{\mathrm{b}}$ \\
\hline \multirow[t]{2}{*}{5903} & Paolina- $\mathrm{T}$ & $17-28 \mathrm{iii}$ & 0 & 5 & 0 & 0 & 5 & 37 & $70^{\mathrm{b}}$ \\
\hline & Stranger & $12-15 \mathrm{iii}$ & 3 & 16 & 0 & 0 & 19 & 3 & $32^{\mathrm{b}}$ \\
\hline \multirow{2}{*}{5904} & Orca & $8-26$ iv & 17 & 48 & 0 & 2 & 67 & 35 & $119^{\mathrm{b}}$ \\
\hline & Paolina-T & $8-24$ iv & 12 & 37 & 0 & 1 & 50 & 29 & $121^{\mathrm{b}}$ \\
\hline \multirow[t]{3}{*}{5905} & Black Douglas & $7-25 v$ & 2 & 14 & 0 & 0 & 16 & 76 & $134^{\mathrm{b}}$ \\
\hline & Orca & $7-26 \mathrm{v}$ & 1 & 26 & 0 & 0 & 27 & 97 & $154^{\mathrm{b}}$ \\
\hline & Paolina-T & $7-17 v$ & 0 & 4 & 0 & 0 & 4 & 43 & $51^{b}$ \\
\hline \multirow[t]{4}{*}{5906} & Black Douglas & $10-26 \mathrm{vi}$ & 2 & 10 & 0 & 0 & 12 & 83 & $110^{\mathrm{b}}$ \\
\hline & Horizon & $15-19$ vi & 5 & 10 & 0 & 0 & 15 & 6 & $22^{\mathrm{k}}$ \\
\hline & Paolina-T & $24-30$ vi & 3 & 8 & 0 & 0 & 11 & 15 & $36^{\mathrm{b}}$ \\
\hline & Orca & $3-17$ vi & 2 & 6 & 0 & 0 & 8 & 78 & $131^{b}$ \\
\hline 5907 & Orca & $10-27$ vii & 8 & 33 & 0 & 2 & 43 & 27 & $131^{\mathrm{b}}$ \\
\hline
\end{tabular}




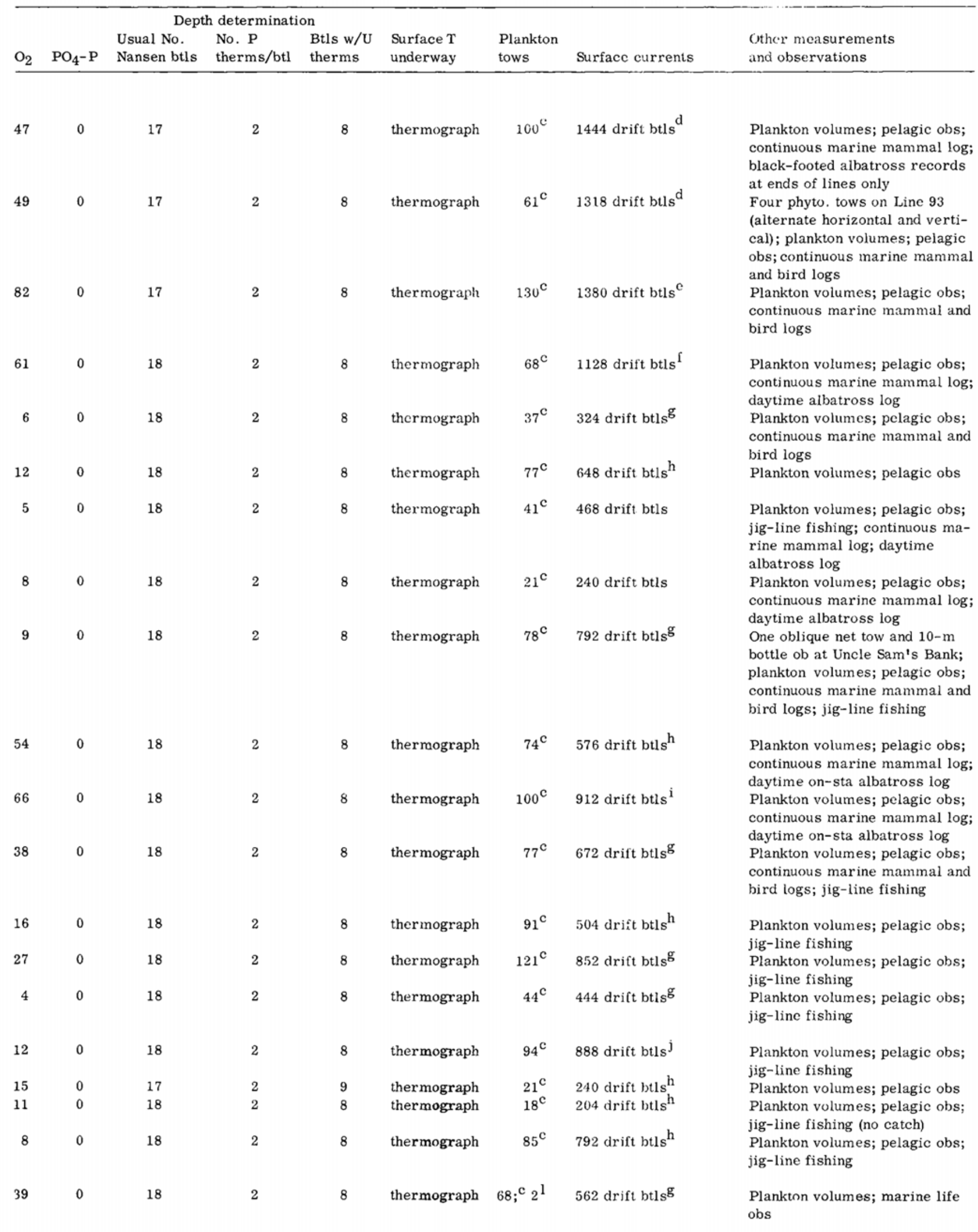




\begin{tabular}{|c|c|c|c|c|c|c|c|c|c|}
\hline \multirow[b]{2}{*}{ Cruise } & \multirow[b]{2}{*}{ Vessel } & \multirow{2}{*}{$\begin{array}{l}\text { Dates of } \\
\text { hydro casts }\end{array}$} & \multicolumn{5}{|c|}{ Number and depths of hydrographic stations } & \multirow{2}{*}{$\begin{array}{l}\mathrm{T} \text { and Sobs } \\
\text { at } 10 \mathrm{~m}\end{array}$} & \multirow{2}{*}{$\begin{array}{l}\text { No. of } \\
\text { BT obs }\end{array}$} \\
\hline & & & $0-500 \mathrm{~m}$ & $500-1000 \mathrm{~m}$ & $1000-2000 \mathrm{~m}$ & $>2000 \mathrm{~m}$ & Total & & \\
\hline 5907 (cont.) & Black Douglas & 9 vii-1 viii & 22 & 59 & 2 & 1 & 84 & 46 & $130^{\mathrm{b}}$ \\
\hline & Black Douglas & $13-25$ viii & 19 & 43 & 0 & 0 & 62 & 29 & $108^{\mathrm{b}}$ \\
\hline $\begin{array}{l}\text { TO-59-2 } \\
\text { Baja California } \\
(5908)\end{array}$ & Hugh M. Smith & $14-29$ viji & 18 & 31 & 0 & 0 & 49 & 15 & $161^{\mathrm{n}}$ \\
\hline
\end{tabular}

5909

Black Douglas

21-27 ix

4

20

0

$0 \quad 24$

10

$52^{\mathrm{b}}$

17

0

$0 \quad 24$

19

65

5910

Spencer F. Baird

$9-26 \times$

22

63

Orca 9-21 $x$

42

Black Douglas

$17-29 x$

39

18

$17-25 x i$

24

9-19 xii

33

Orca

6

9

4

19

$0 \quad 32$

182

$17 \mathrm{i}-22$ ii

Stranger $^{\mathrm{a}}$ 
INFORMATION (cont.)

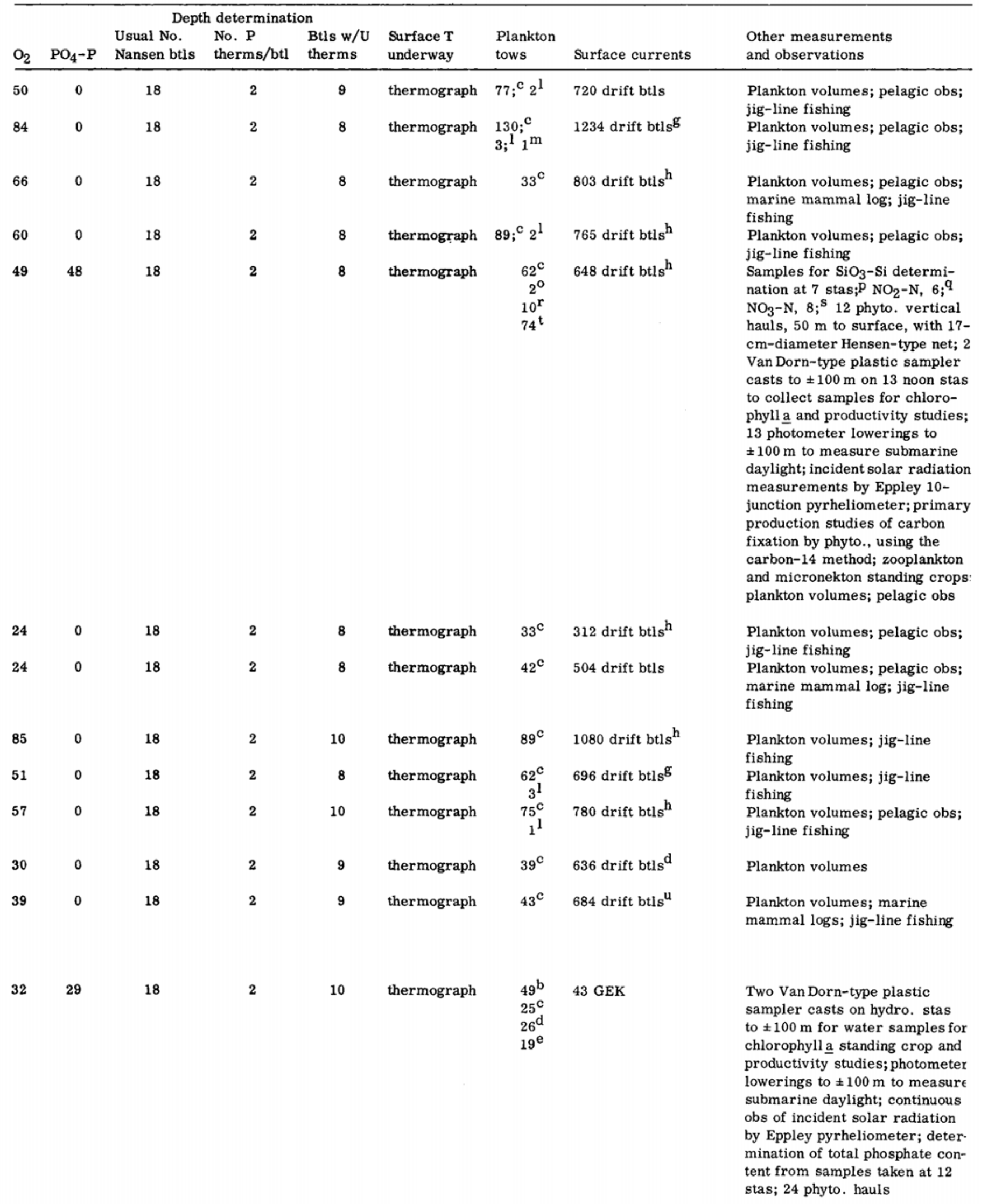




\begin{tabular}{|c|c|c|c|c|c|c|c|c|c|}
\hline \multirow[b]{2}{*}{ Cruise } & \multirow[b]{2}{*}{ Vessel } & \multirow{2}{*}{$\begin{array}{l}\text { Dates of } \\
\text { hydro casts }\end{array}$} & \multicolumn{5}{|c|}{ Number and depths of hydrographic stations } & \multirow{2}{*}{$\begin{array}{l}\mathrm{T} \text { and Sobs } \\
\text { at } 10 \mathrm{~m}\end{array}$} & \multirow{2}{*}{$\begin{array}{l}\text { No. of } \\
\text { BT obs }\end{array}$} \\
\hline & & & $0-500 \mathrm{~m}$ & $500-1000 \mathrm{~m}$ & $1000-2000 \mathrm{~m}$ & $>2000 \mathrm{~m}$ & Total & & \\
\hline
\end{tabular}

Hugh M. Smith ${ }^{\mathrm{a}}$

4-18 ix

2

1

14

0

17

94

Vermilion Sea

Spencer F. Baird ${ }^{\mathrm{a}}$

16 iv- $24 \mathrm{v}$

15

$\underline{\text { SIO/IGY }}$

Dorado

Horizon $^{\mathrm{a}}$

12 vii-16 viii

1

Spencer F. Baird ${ }^{\mathrm{a}}$

11 xi-6 xii

Costa Rica Dome

$\underline{\text { SBL }}$

Ocean-1

MV Pioneer

24 iv-28 viii

49
7

6

47

0

240

1

50

0

59

0

$426^{\mathrm{b}}$

6

38

0

93

0

$161^{\mathrm{a}}$ 
INFORMATION (cont.)

\begin{tabular}{|c|c|c|c|c|c|c|c|c|}
\hline $\mathrm{O}_{2}$ & $\mathrm{PO}_{4}-\mathrm{P}$ & $\begin{array}{l}\text { Dept } \\
\text { Usual No. } \\
\text { Nansen btls }\end{array}$ & $\begin{array}{l}\text { determinati } \\
\text { No. } \mathrm{P} \\
\text { therms/btl }\end{array}$ & $\begin{array}{l}\text { on } \\
\text { Btls w/U } \\
\text { therms }\end{array}$ & $\begin{array}{l}\text { Surface T } \\
\text { underway }\end{array}$ & $\begin{array}{l}\text { Plankton } \\
\text { tows }\end{array}$ & Surface currents & $\begin{array}{l}\text { Other measurements } \\
\text { and observations }\end{array}$ \\
\hline 17 & 17 & 18 & 2 & 8 & thermograph & $\begin{array}{l}19^{\mathrm{b}} \\
15^{\mathrm{c}} \\
11^{\mathrm{d}} \\
13^{\mathrm{e}} \\
62^{\mathrm{f}}\end{array}$ & 32 GEK & $\begin{array}{l}\text { Two Van Dorn-type plastic } \\
\text { sampler casts on hydro. stas to } \\
\pm 100 \mathrm{~m} \text { for water samples for } \\
\text { chlorophyll a standing crop and } \\
\text { productivity studies; submarine } \\
\text { photometer lowerings to } \pm 100 \mathrm{~m} \\
\text { to measure submarine daylight; } \\
\text { continuous obs of incident solar } \\
\text { radiation by Eppley pyrheli- } \\
\text { ometer; samples for } \mathrm{NO}_{2}-\mathrm{N} \\
\text { determination collected at } \mathrm{Stas} \text {. } \\
68 \text { and } 78 \text {; samples for } \mathrm{NO}_{3}-\mathrm{N} \\
\text { determination collected at } \mathrm{Sta} \text {. } \\
68 \text {; } 6 \text { phyto. hauls }\end{array}$ \\
\hline 47 & 0 & 18 & 2 & 8 & thermograph & 0 & - & $\begin{array}{l}\text { Geological and geophysical } \\
\text { exploration of the Gulf of } \\
\text { California }\end{array}$ \\
\hline
\end{tabular}

20

2

12

thermograph

\section{0}

88 GEK
Current measurements with 26 neutrally buoyant ("Swallow") floats

Samples for $\mathrm{SiO}_{3}-\mathrm{Si}$ determination at 18 stas; ${ }^{\mathrm{f}} \mathrm{NO}_{2}-\mathrm{N}$, 18 f $^{\mathrm{f}} \mathrm{NO}_{3}-\mathrm{N}, 18 ;$ f $^{2}$ stas to measure currents with reference to parachute drogue at $1000 \mathrm{~m}$ using modified Roberts meter; incident solar radiation measurements by pyrheliometer; radioactivity determinations; carbon fixation measurements by C- 14 method; surface and subsurface samples to $200 \mathrm{~m}$ or less collected with Van Dorn plastic samplers to determine chlorophyll a concentration and primary production; water transparency measurements by submarine photometer cast to $100 \mathrm{~m}$ or less

Investigation of distribution and migration of salmon; gill-net fishing; 16 night surface hauls with modified Isaacs-Kidd trawl; ${ }^{f}$ numbers of 10 different organisms and numbers of copepods (12 species) per cubic meter of water filtered during plankton hauls 
SUMMARY CRUISE

\begin{tabular}{|c|c|c|c|c|c|c|c|c|c|}
\hline \multirow[b]{2}{*}{ Cruise } & \multirow[b]{2}{*}{ Vessel } & \multirow{2}{*}{$\begin{array}{l}\text { Dates of } \\
\text { hydro casts }\end{array}$} & \multicolumn{5}{|c|}{ Number and depths of hydrographic stations } & \multirow{2}{*}{$\begin{array}{l}\mathrm{T} \text { and Sobs } \\
\text { at } 10 \mathrm{~m}\end{array}$} & \multirow{2}{*}{$\begin{array}{l}\text { No. of } \\
\text { BT obs }\end{array}$} \\
\hline & & & $0-500 \mathrm{~m}$ & $500-1000 \mathrm{~m}$ & $1000-2000 \mathrm{~m}$ & $>2000 \mathrm{~m}$ & Total & & \\
\hline
\end{tabular}

King Crab

Investigations

$\underline{\text { POG }}$

PAPA, P-59-1 CGS St. Catharines ${ }^{\mathrm{a}} 25 \mathrm{i}-3 \mathrm{iji}$

PAPA, P-59-2

CGS St. Catharines $^{\mathrm{a}} 14 \mathrm{iv}-31 \mathrm{v}$

10

0

3

10

5

0

0

43

0

170

PAPA, P-59-3 CGS St. Catharines ${ }^{\mathrm{a}} 8$ vii-23 viii

6

0

19

0

25

0

149 
INFORMATION (cont.)

\begin{tabular}{|c|c|c|c|c|c|c|c|c|}
\hline \multirow[b]{2}{*}{$\mathrm{O}_{2}$} & \multirow[b]{2}{*}{$\mathrm{PO}_{4}-\mathrm{P}$} & \multicolumn{3}{|c|}{ Depth determination } & \multirow[b]{2}{*}{$\begin{array}{l}\text { Surface T } \\
\text { underway }\end{array}$} & \multirow[b]{2}{*}{$\begin{array}{l}\text { Plankton } \\
\text { tows }\end{array}$} & \multirow[b]{2}{*}{ Surface currents } & \multirow[b]{2}{*}{$\begin{array}{l}\text { Other measurements } \\
\text { and observations }\end{array}$} \\
\hline & & $\begin{array}{l}\text { Usual No. } \\
\text { Nansen btls }\end{array}$ & $\begin{array}{l}\text { No. P } \\
\text { therms/btl }\end{array}$ & $\begin{array}{l}\text { Btls w/U } \\
\text { therms }\end{array}$ & & & & \\
\hline $53^{b}$ & 0 & $\begin{array}{l}\text { deep, } 4 \\
\text { shallow, } 11\end{array}$ & $\begin{array}{l}2 \\
2\end{array}$ & $\begin{array}{l}4 \\
6\end{array}$ & - & $\begin{array}{l}33^{\mathrm{d}} \\
32^{\mathrm{e}}\end{array}$ & - & $\begin{array}{l}\text { Investigation of distribution and } \\
\text { migration of salmon; gill-net } \\
\text { fishing; } 31 \text { night surface hauls } \\
\text { with modified Isaacs-Kidd } \\
\text { trawl; numbers of } 10 \text { different } \\
\text { organisms and numbers of } \\
\text { copepods ( } 12 \text { species) per cubic } \\
\text { meter of water filtered during } \\
\text { plankton hauls }\end{array}$ \\
\hline 0 & 0 & 4 & 2 & 0 & - & 0 & - & $\begin{array}{l}\text { Survey of the benthic inverte- } \\
\text { brate fauna (pelecypods, gas- } \\
\text { tropods, barnacles, decapod } \\
\text { crustaceans, tunicates, and the } \\
\text { majority of echinoderms) col- } \\
\text { lected in the eastern Bering Sea } \\
\text { using otter trawls and a box- } \\
\text { type dredge }\end{array}$ \\
\hline
\end{tabular}

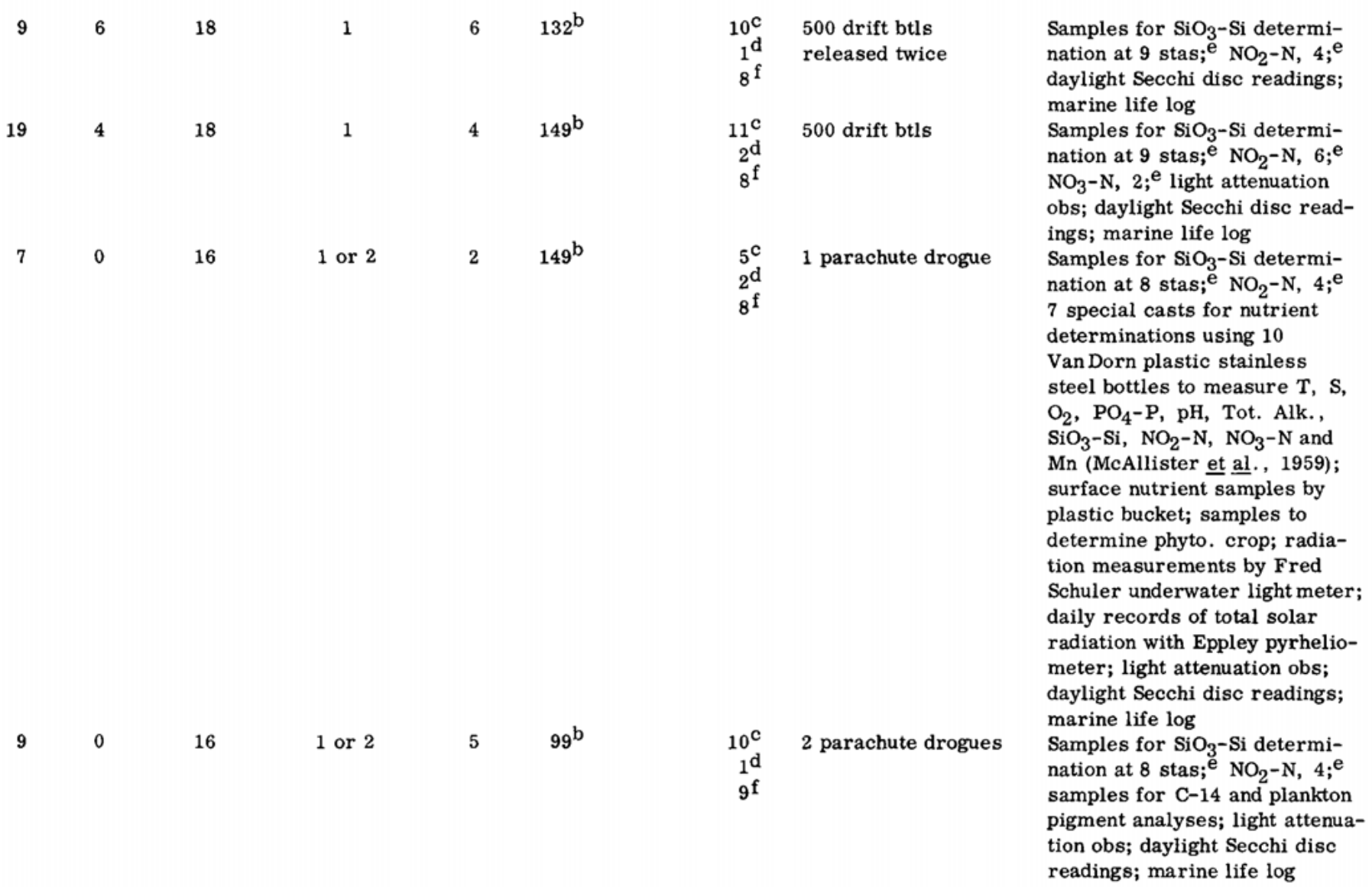


SUMMARY CRUISE

\begin{tabular}{|c|c|c|c|c|c|c|c|c|c|}
\hline \multirow[b]{2}{*}{ Cruise } & \multirow[b]{2}{*}{ Vessel } & \multirow{2}{*}{$\begin{array}{l}\text { Dates of } \\
\text { hydro casts }\end{array}$} & \multicolumn{5}{|c|}{ Number and depths of hydrographic stations } & \multirow{2}{*}{$\begin{array}{l}\mathrm{T} \text { and Sobs } \\
\text { at } 10 \mathrm{~m}\end{array}$} & \multirow{2}{*}{$\begin{array}{l}\text { No. of } \\
\text { BT obs }\end{array}$} \\
\hline & & & $0-500 \mathrm{~m}$ & $500-1000 \mathrm{~m}$ & $1000-2000 \mathrm{~m}$ & $>2000 \mathrm{~m}$ & Total & & \\
\hline PAPA, P-59-5 & CGS St. Catharines ${ }^{g}$ & $\begin{array}{l}9 \text { xii } 1959- \\
24 \text { i } 1960\end{array}$ & 5 & 2 & 11 & 0 & 18 & 0 & 107 \\
\hline
\end{tabular}

NP-59-1

CS-59-1

CS-59-2

NP-59-2

NP-59-3

CS-59-3

USCGS
$20 \mathrm{i}-15 \mathrm{ii}$

CNAV Oshawa $\mathrm{m}$

31 iii-22 iv

12

115

3

8

18

54

0

2

25

114

5

CNAV Oshawa ${ }^{\mathrm{m}} \quad 8 \mathrm{vi}-1$ vii

.

0

144

0

$236^{\mathrm{n}}$

76

$176^{\mathrm{n}}$
CNAV Oshawa $^{\mathrm{m}} \quad 4$ viii-1 ix

CNAV Whitethroat ${ }^{\mathrm{m}} \quad$ 4-29 viii

CNAV Oshawa ${ }^{\mathrm{m}}$

$16 \mathrm{xi}-11 \mathrm{xii}$

84

5
11

9

6
56

41

0

95

0

$119^{\mathrm{n}}$
USCGSS Explorer

$26 \mathrm{v}-18 \mathrm{vi}$

3

USNOO

USS Staten Island $\quad 10-11$ ix

UW

BB-234

BB-235
Brown Bear ${ }^{\mathrm{a}}$

$18-29$ vi

Brown Bear ${ }^{2}$

$16-31$ vii
38

7
4

0

5

1
0

1

0

14

9

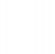

150

121 
INFORMATION (cont.)

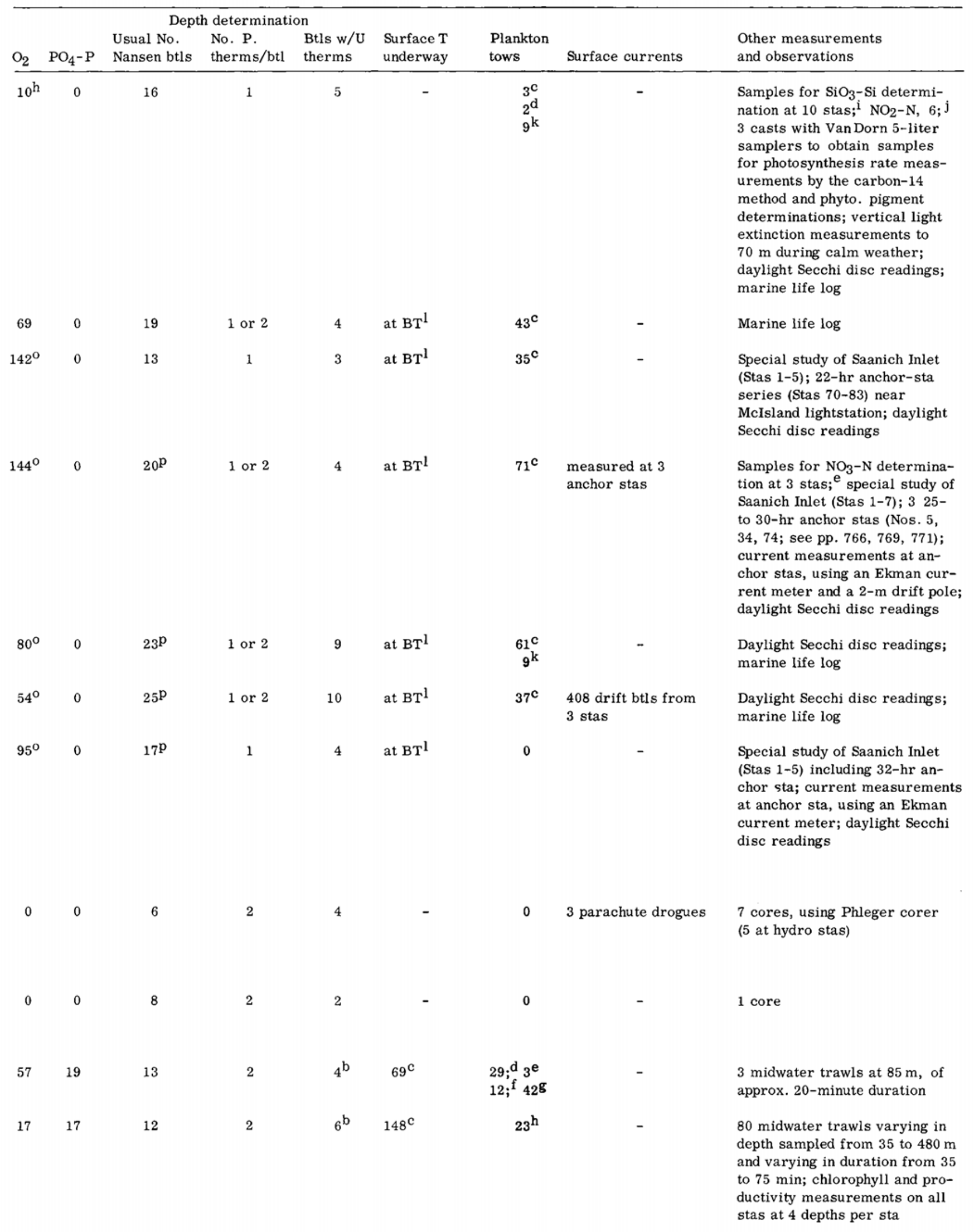




\section{General Methods}

Unless otherwise indicated, subsurface temperature by paired reversing thermometers; salinity by Knudsen method (reported to hundredths) or by conductivity bridge (reported to thousandths); dissolved oxygen by Winkler method aboard ship; inorganic phosphate by the molybdenum-blue method (Wooster and Rakestraw, 1951).

When available, specific information on accuracy is indicated by footnotes. Absence of such information does not imply that the nominal accuracies have been achieved.

$\underline{\mathrm{CCOFI}}$

a CCOFI thermometer calibrations indicate the temperature accuracy to be $0.02^{\circ} \mathrm{C}$; field tests indicate a salinity accuracy of $\pm 0.025 \%$ (root mean square).

b Lowerings with 450-ft BT on station, "underway" between stations (ship stopped), and for calibration checks.

c Oblique plankton tow to approximately $140 \mathrm{~m}$ (200 m of wire out, or less in shallow water) taken with a $30 \mathrm{XXX}$ net, $1.0 \mathrm{~m}$ in diameter at mouth by approximately $5 \mathrm{~m}$ in over-all length with detachable cod end of 56XXX nylon grit gauze.

d Total number released, 12 ballasted and 12 unballasted at each designated station.

e Total number released, 12 ballasted green bottles per station except on Sta. 157.10 where 24 were released.

f Total number released, 12 or 24 per designated station as scheduled.

g Total number released, 12 ballasted bottles per designated station.

h Total number released, 12 per designated station.

i Total number released, 12 per station except on Stas. $73.70,73.80$ and 73.90 where 12 ballasted and 12 unballasted clear glass bottles were released.

j Total number released, 12 per designated station except Stas. 93.28, 100.29 and between South Coronado Island and the mainland where 24 were released.

k On-station observations only.

l Oblique plankton tow to approximately $424 \mathrm{~m} \mathrm{(600} \mathrm{m} \mathrm{of} \mathrm{wire} \mathrm{out,} \mathrm{or} \mathrm{less} \mathrm{in} \mathrm{shallow} \mathrm{water)} \mathrm{taken}$ with a $30 \mathrm{XXX}$ net, $1.0 \mathrm{~m}$ in diameter at mouth by approximately $5 \mathrm{~m}$ in over-all length with detachable cod end of $56 \mathrm{XXX}$ nylon grit gauze.

m Special plankton tow on Uncle Sam's Bank.

n Approximately half of lowerings made with $900-\mathrm{ft} \mathrm{BT}$.

- Horizontal plankton tow taken just below the sea surface with a $30 \mathrm{XXX}$ net, $1.0 \mathrm{~m}$ in diameter at mouth by approximately $5 \mathrm{~m}$ in over-all length with detachable cod end of $56 \mathrm{XXX}$ nylon grit gauze.

p Silicate measured by forming the silicomolybdate complex followed by reduction with metoloxalic acid solution; final determination by Beckman DU spectrophotometer (Strickland, 1958a, b). Variations in reagent blanks resulted in errors of $\pm 0.05 \mu \mathrm{g}$ at $/ \mathrm{L}$.

q Nitrite measured by diazotization with sulfanilamide followed by coupling to $\mathrm{N}$ (1 naphthyl) ethylene diamine; final determination by Beckman DU spectrophotometer (Strickland, 1958a, b). Variations in reagent blanks resulted in errors of $\pm 0.02 \mu \mathrm{g}$ at/L.

$\mathrm{r}$ Oblique high-speed micronekton haul in the upper $90 \mathrm{~m}$ of water at night stations at a speed of $5 \mathrm{kt}$, using a very coarse-meshed plankton net about $20 \mathrm{ft}$ in over-all length with a 5-ft-square mouth opening, terminating in a detachable meter-net cod end of $56 \mathrm{XXX}$ nylon grit gauze.

s Nitrate measured by reduction to nitrite with hydrazine. Analyses for nitrate were less satisfactory than for nitrite and silicate: duplicates sometimes did not agree to within $\pm \mathbf{5}$ per cent of a mean value, in which case the results were rejected. The slope of the nitrate calibration curve varied greatly from station to station, probably because of the motion of the ship. Variations in reagent blanks resulted in errors of $\pm 0.1 \mu \mathrm{g}$ at $/ \mathrm{L}$ for nitrate.

t Micronekton surface haul taken with a high-speed conical nylon net $70 \mathrm{~cm}$ in diameter at mouth by about $8-1 / 2 \mathrm{ft}$ in over-all length, with detachable meter-net cod end of 56XXX nylon grit gauze, towed in the upper $10 \mathrm{~m}$ with $50 \mathrm{~m}$ of wire out at a speed of 9 to $10 \mathrm{kt}$ for periods of from 2 to 3 hours.

u Total number released: 24 from all hydrographic stations on Lines 77 and 80; on Lines 83, 87, 90 and 93,12 from each inshore station and each offshore hydrographic station.

SIO

a Thermometer calibrations indicate the temperature accuracy to be $0.02^{\circ} \mathrm{C}$; field tests indicate a salinity accuracy of $\pm 0.025 \%$ (root mean square). 


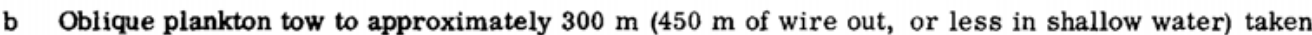
with a $30 \mathrm{XXX}$ net, $1.0 \mathrm{~m}$ in diameter at mouth by approximately $5 \mathrm{~m}$ in over-all length with detachable cod end of $56 \times x \times$ nylon grit gauze.

c Horizontal plankton tow taken just below the sea surface with a $30 \mathrm{XXX}$ net, $1.0 \mathrm{~m}$ in diameter at mouth by approximately $5 \mathrm{~m}$ in over-all length with detachable cod end of 56XXX nylon grit gauze.

d Horizontal plankton tow taken with a closing Clarke-Bumpus net with a mouth diameter of $25 \mathrm{~cm}$. Routinely a series of three 15- or 30-minute hauls was made at each station where the samplers were used: one haul in the center of the mixed layer, one in the thermocline, and one well below the thermocline.

e Oblique high-speed micronekton hauls in the upper $90 \mathrm{~m}$ of water at night stations at a speed of $5 \mathrm{kt}$, using a very coarse-meshed plankton net about $20 \mathrm{ft}$ in over-all length with a 5-ft-square mouth opening, terminating in a detachable meter-net cod end of 56XXX nylon grit gauze.

f Micronekton surface haul taken with a high-speed conical nylon net $70 \mathrm{~cm}$ in diameter at mouth by about $8-1 / 2 \mathrm{ft}$ in over-all length, with detachable meter-net cod end of $56 \mathrm{XXX}$ nylon grit gauze, towed in the upper $10 \mathrm{~m}$ with $50 \mathrm{~m}$ of wire out at a speed of 9 to $10 \mathrm{kt}$ for periods of from 2 to 3 hours.

\section{$\underline{\text { IATTC/SIO }}$}

a Salinity determinations by University of Washington-Pacific Naval Laboratory conductivity salinometer (Paquette, 1958). The 1023 salinity values are the means of duplicate determinations except in six cases in which there was a single determination and forty-one cases in which a triplicate determination was necessary. The standard deviation from the means of the 976 duplicate determinations was $0.022 \%$.

b BT lowerings to $125 \mathrm{~m}$ on station and every 10 miles in the Dome area; to $270 \mathrm{~m}$ every 30 miles north of $12^{\circ} \mathrm{N}$.

c Inorganic phosphate determined by the method described by Strickland (1958a) except that the extinction coefficient $\mathrm{k}$ was determined by Wooster and Rakestraw (1951).

d Standard surface zooplankton haul taken with a net, $1.0 \mathrm{~m}$ in mouth diameter, of nylon grit gauze (No. 452 Nitex in the body and No. 295 Nitex in the rear section and cod end). A Tsurumi flowmeter was mounted in the mouth. The net was towed from the side of the ship with about $15 \mathrm{~m}$ of wire out, usually at a depth of less than $5 \mathrm{~m}$, for a period of 15 minutes.

e Standard oblique zooplankton haul taken with a net, $1.0 \mathrm{~m}$ in mouth diameter, of nylon grit gauze (No. 452 Nitex in the body and No. 295 Nitex in the rear section and cod end). The net was lowered from the surface to a depth of approximately $300 \mathrm{~m}(450 \mathrm{~m}$ of wire out) at a rate of $50 \mathrm{~m}$ per minute while the vessel moved slowly underway and it was retrieved at a rate of $20 \mathrm{~m}$ per minute. (Duration of a single haul, therefore, was about 32 minutes, on the average.) A Tsurumi flowmeter was mounted in the mouth of the net to record the volume of sea water filtered by the net.

f Water samples were filtered, frozen and stored for analyses ashore to determine nitrite, nitrate and silicate concentration using the methods given by Strickland (1958b) .

g Simultaneous horizontal closing-net hauls were made with enlarged Clarke-Bumpus samplers using nylon grit gauze (No. 706 Nitex in the body and No. 316 Nitex in the cod end). A Tsurumi flowmeter was mounted in the mouth. Three Clarke-Bumpus samplers were fastened to the wire so that, when lowered, they sampled depths above, in and below the thermocline, or above, in and below the oxygen minimum layer; the samplers were kept open for 30 minutes during the tow and the wire angle was kept as close as possible to $45^{\circ}$.

$\underline{\mathrm{SBL}}$

a BT lowerings to $275 \mathrm{~m}$

b All oxygen samples except those collected on the return voyage were analyzed by Winkler method in Adak, Alaska, through the cooperation of the U. S. Navy. (The other samples were analyzed in Seattle.)

c An experimental temperature-conductivity cell was towed astern to provide a continuous record of surface temperature and salinity. The cell, designed and constructed by the Fisheries Instrumentation Laboratory, Seattle, requires further modifications and improvements before it can be considered operational (Favorite et al., 1961).

d Vertical haul with one-half-meter net, No. 6 mesh, at about $50 \mathrm{~m}$ per minute from $30 \mathrm{~m}$ to surface.

e Vertical haul with one-half-meter net, No. 6 mesh, at about $50 \mathrm{~m}$ per minute from $150 \mathrm{~m}$ to surface.

f Trawl towed at the surface at $6 \mathrm{kt}$ for 15 minutes about one hour after evening twilight in vicinity of gill nets, weather permitting. 
g The otter trawls were towed on a straight-line course at approximately 3 miles per hour for 1-hour periods at stations spaced at 20-mile intervals throughout the area. The trawl used was a standard " 400 mesh eastern" type with a 94-ft-long footrope. To assure the retention of smaller organisms, the trawl was modified by inserting a 1-1/2-inch mesh lining to the cod end. The box-type dredge was used for additional sampling at some stations. The galvanized screening of the dredge had four openings to the inch; in addition, it was lined with $1 / 8$-inch mesh netting (McLaughlin, 1963).

$\underline{\text { POG }}$

a Salinity samples were analyzed ashore in a modified Wenner-Smith-Soule conductivity bridge; accuracy, $\pm 0.01 \%$.

b A bucket surface temperature, using a chemical thermometer graduated in $0.5^{\circ} \mathrm{C}$ intervals, was obtained at each BT ob.

c Vertical plankton tow, $150 \mathrm{~m}$ to surface, using a net one-half $\mathrm{m}$ in diameter, of mesh size 0.33 $\mathrm{mm}$, hauled in at a speed of one $\mathrm{m}$ per second.

d Vertical plankton tow, $1250 \mathrm{~m}$ to surface, using a net one-half $\mathrm{m}$ in diameter, of mesh size $0.33 \mathrm{~mm}$.

e Chemical analyses aboard ship using the methods described by Strickland $(1958 \mathrm{a}, \mathrm{b})$.

f Surface horizontal plankton tow of 20-minute duration one hour after sunset (series of three made on consecutive evenings at the beginning, middle and end of cruise).

g Salinity values are the means of duplicate determinations. The correct value lies in the range of $\pm 0.004 \%$ at the $95 \%$ probability level (Strickland, 1958b).

$\mathrm{h}$ Dissolved oxygen by a modified Winkler method, generally from a single determination, except those samples from depths greater than $2000 \mathrm{~m}$ which are from duplicates. The correct value lies in the range $\pm 0.003 \mathrm{mg}$ at/ $\mathrm{L}$ (Strickland and Parsons, 1960).

i Silicate by the method of Mullin and Riley. Values are from a single determination of each analysis. Method and limits of accuracy explained by Strickland and Parsons (1960).

j Nitrite by the method of Bendschneider and Robinson. Values are from a single determination of each analysis. Limits of accuracy and method explained by Strickland and Parsons (1960) .

$\mathrm{k}$ Surface horizontal plankton tow of 10-minute duration hauled at a speed of 2-3 kt (series of three made on consecutive evenings at the beginning, middle and end of cruise).

1 A bucket temperature, using a chemical thermometer graduated in $0.5^{\circ} \mathrm{C}$ intervals was obtained at BT obs between stations.

m Determination of salinity aboard ship using a conductivity salinometer (Paquette, 1958; Strickland, 1958a).

n BT obs on station and midway between stations on the 200-mile offshore sections.

- Dissolved oxygen by Winkler method described by Strickland (1958a).

p Fjarlie sampling bottles sometimes used.

USNOO

a Hourly observations obtained with $450-\mathrm{ft}$ BT in the area where hydrographic stations were occupied.

$\underline{\mathrm{UW}}$

a Salinity determinations by University of Washington-Pacific Naval Laboratory salinometer which is a modification of the Wenner-Smith-Soule salinity bridge (Paquette, 1958). All values reported are the means of duplicates. Such values have a reproducibility of $\pm 0.004 \%$ salinity at the 95 per cent probability level and a probable accuracy of $\pm 0.01 \%$ salinity or better at the same level of probability.

b Usual number on deep stations.

c Obtained in conjunction with underway BT obs.

d Oblique plankton tow taken with Clarke-Bumpus net $14 \mathrm{~cm}$ in mouth diameter, $1.0 \mathrm{~m}$ in length, of No. 6 mesh. One sampler only was used on the wire for each tow. Sampling depths varied, ranging from 0 to $230 \mathrm{~m}$, and duration varied, usually between 15 to 30 minutes.

e Horizontal plankton tow taken with Clarke-Bumpus net $14 \mathrm{~cm}$ in mouth diameter, $1.0 \mathrm{~m}$ in length, of No. 6 mesh. One sampler only was used on the wire for each tow. All tows were made on Sta. 20: No. 1 at $64 \mathrm{~m}$, No. 2 at $56 \mathrm{~m}$ and No. 3 at $35 \mathrm{~m}$.

f Stepped plankton tows taken with Clarke-Bumpus net $14 \mathrm{~cm}$ in mouth diameter, $1.0 \mathrm{~m}$ in length, of No. 6 mesh. One sampler only was used on the wire for each tow; usually tows lasted 5 minutes at each of three depths or 10 minutes at each of two depths, the depths ranging from 0 to $150 \mathrm{~m}$.

g Vertical net tows, surface to approximately $200 \mathrm{~m}$, using half-meter net, $50 \mathrm{~cm}$ in mouth diameter, $1.5 \mathrm{~m}$ in length, of No. 6 mesh, and from approximately 12 to 20 minutes in duration.

$\mathrm{h}$ Vertical net tow, surface to approximately $400 \mathrm{~m}$, using half-meter net, $50 \mathrm{~cm}$ in mouth diameter, $1.5 \mathrm{~m}$ in length, of No. 6 mesh, and from 12 to 20 minutes in duration. 


\section{Bibliography}

\section{LITERATURE CITED IN THIS VOLUME}

AUSTIN, THOMAS S.

1962 Amendment to the correction in Deep-Sea Research, volume 8, No. 2, p. 152. Deep-Sea Res., $\underline{9}(1)$ : 75-76

BLACKBURN, MAURICE, RAYMOND C. GRIFFITHS, ROBERT W. HOLMES and

WILLIAM H. THOMAS

1962 Physical, chemical, and biological observations in the eastern tropical Pacific Ocean: three cruises to the Gulf of Tehuantepec, 1958-59. Spec. sci. Rep. U. S. Fish Wildl. Serv., Fish. No. 420: 1-170

CARRITT, DAYTON E., and JAMES H. CARPENTER

1959 The composition of sea water and the salinity-chlorinity-density problems. Proc. Conf. phys. chem. Prop. Sea Water, NAS-NRC Publ. 600: 67-86

ECKART, CARL

1958 Properties of water, part II. The equation of state of water and sea water at low temperatures and pressures. Amer. J. Sci., 256 (4): 225-240

EKMAN, V. WALFRID

1908 Die Zusammendrlickbarkeit des Meerwassers nebst einigen Werten fur Wasser und Quecksilber. Publ. Circ. Cons. int. Explor. Mer, No. 43: 1-47

FAVORITE, FELIX, RICHARD J. CALLAWAY and JAMES F. HEBARD

1961 North Pacific and Bering Sea oceanography, 1959. Spec. sci. Rep. U. S. Fish Wildl. Serv., Fish. No. 377: 1-116

FOFONOFF, N. P., and C. FROESE

1958 Program for oceanographic computations and data processing on the electronic digital computer ALWAC HI-E. PSW-1 Programs for properties of sea water. Fish. Res. Bd. Canada, MS Rep. Ser. (Oceanogr. Limnol.), No. 27: 1-39

FOFONOFF, N. P., and S. TABATA

1958 Program for oceanographic computations and data processing on the electronic digital computer ALWAC III-E. DP-1 Oceanographic station data program. Fish. Res. Bd. Canada, MS Rep. Ser. (Oceanogr. Limnol.), No. 25: 1-38

FROESE, C.

1960 Programs for oceanographic computations and data processing on the electronic digital computer ALWAC III-E. DP-3 Oceanographic station data program. Fish. Res. Bd. Canada, MS Rep. Ser. (Oceanogr. Limnol.), No. 73: 1-23

KNUDSEN, MARTIN

1901 Hydrographical tables. Copenhagen, G. E. C., GAD.: 1-63

MCALLISTER, C. D., T. R. PARSONS and J. D. H. STRICKLAND

1959 Data record, ocean fertility and productivity measurements at Ocean Weather Station "P," July and August 1959. Fish. Res. Bd. Canada, MS Rep. Ser. (Oceanogr. Limnol.), No. 55: $1-31$

MeLAUGHLIN, PATSY A.

1963 Survey of the benthic invertebrate fauna of the eastern Bering Sea. Spec. sci. Rep. U. S. Fish Wildl. Serv., Fish. No. 401: 1-75

MONTGOMERY, R. B., and WARREN S. WOOSTER

1954 Thermosteric anomaly and the analysis of serial oceanographic data. Deep-Sea Res., 2(1): $63-70$

NATIONAL OCEANOGRAPHIC DATA CENTER

1962 Processing physical and chemical data from oceanographic stations. Manual Ser., Publ. M-2: $1-105$

PAQUETTE, ROBERT G.

1958 A modification of the Wenner-Smith-Soule salinity bridge for the determination of salinity in sea water, with details of construction, operation, and maintenance. Univ. Wash., Dep. Oceanogr., Tech. Rep. No. 61: 1-58

POLLAK, MARTIN J.

1961 Units for specific volume of sea water. J. Mar. Res., 199(1): 28-29

RED, R. O.

1959 Influence of some errors in the equation of state or in observations on geostrophic currents. Proc. Conf. phys. chem. Prop. Sea Water, NAS-NRC Publ. 600: 10-29 
SCRIPPS INSTITUTION OF OCEANOGRAPHY OF THE UNIVERSITY OF CALIFORNIA

1960 Physical, chemical and biological data, Costa Rica Dome cruise, 6 November - 14 December 1959. Scripps Instn. Oceanogr., Data Rep., SIO Ref. 60-20: 1-33

STRICKLAND, J. D. H.

1958a Standard methods of seawater analyses, Volume I. A reprinting including recent addenda. Fish. Res. Bd. Canada, MS Rep. Ser. (Oceanogr. Limnol.), No. 18: 1-143

1958b Standard methods of seawater analyses, Volume II. Fish. Res. Bd. Canada, MS Rep. Ser. (Oceanogr. Limnol.), No. 19: 1-78

STRICKLAND, J. D. H., and T. R. PARSONS

1960 A manual of sea water analysis (with special reference to the more common micronutrients and to particulate organic material). Bull. Fish. Res. Bd. Canada, No. 125: 1-185

SVERDRUP, H. U., MARTIN W. JOHNSON and RICHARD H. FLEMING

1946 The oceans, their physics, chemistry, and general biology. New York, Prentice-Hall, Inc. : $1-1087$

UNITED STATES NAVY HYDROGRAPHIC OFFICE (U. S. NAVAL OCEANOGRAPHIC OFFICE)

1960 Manual for coding and punching oceanographic data on cards (oceanographic station data). Hydrogr. Off. Spec. Publ. 12(part III): 1-22

WOOSTER, WARREN S., and NORRIS W. RAKESTRAW

1951 The estimation of dissolved phosphate in sea water. J. Mar. Res., 10(1): 91-100

WOOSTER, WARREN S., and BRUCE A. TAFT

1958 On the reliability of field measurements of temperature and salinity in the ocean. J. Mar. Res., 17: 552-566

PUBLICATIONS IN WHICH USE WAS MADE OF DATA COLLECTED ON THE CRUISES PRESENTED IN THIS VOLUME

AHLSTROM, ELBERT H. , and JAMES R. THRAILKILL

1963 Plankton volume loss with time of preservation. In Calif. Cooperative Fish. Invest., Reps., 1 July 1960 to 30 June 1962, Mar. Res. Comm., 9: 57-73

ALVARIÑO, ANGELES

1962a Taxonomic revision of Sagitta robusta and Sagitta ferox Doncaster, and notes on their distribution in the Pacific. Pacif. Sci., 16(2): 186-201

1962b Two new Pacific chaetognaths, their distribution and relationship to allied species. Bull. Scripps Instn. Oceanogr., $\underline{8}(1): 1-50$

Bathymetric distribution of chaetognaths. Pacif. Sci., $\underline{18}(1) \quad$ (in press)

The chaetognaths of the Monsoon Expedition in the Indian Ocean. Pacif. Sci. (in press) Zoogeografía de los quetognatos, especialmente en la región de California. Contr. Biogeogr. Mar. Organisms. Centro de Cooperación Científica, Ibero-América (UNESCO) (in press)

BERNER, LEO D., and JOSEPH L. REID, JR.

1961 On the response to changing temperature of the temperature-limited plankter Doliolum denticulatum Quoy and Gaimard 1835. Limnol. Oceanogr., 6(2): 205-215

BIEN, G. S., N. W. RAKESTRAW and H. E. SUESS

1960 Radiocarbon concentration in Pacific Ocean water. Tellus, 12(4): 436-443

BLACKBURN, MAURICE

1962 An oceanographic study of the Gulf of Tehuantepec. Spec. sci. Rep. U. S. Fish Wildl. Serv., Fish. No. 404: 1-28

BLACKBURN, MAURICE, and ASSOCLATES

1962 Tuna oceanography in the eastern tropical Pacific. Spec. sci. Rep. U. S. Fish Wildl. Serv., Fish. No. 400: 1-48

BLACKBURN, MAURICE, RAYMOND C. GRIFFITHS, ROBERT W. HOLMES and

WILLIAM H. THOMAS

1962 Physical, chemical, and biological observations in the eastern tropical Pacific Ocean: three cruises to the Gulf of Tehuantepec, 1958-1959. Spec. sci. Rep. U. S. Fish Wildl. Serv., Fish. No. 420: 1-170 
BOGDANOV, K. T.

1961 Water circulation in the Gulf of Alaska and its seasonal variability. Okeanologiya, $\underline{1}(5)$ : 815-824 (Russian-English translation in Deep-Sea Res., 10 (4): 479-487, 1962)

BOYD, CARL M., and MARTIN W. JOHNSON

1963 Variations in the larval stages of a decapod crustacean, Pleuroncodes planipes Stimpson (Galatheidae). Biol. Bull., 124(3): 141-152

BRINTON, EDWARD

1962a The distribution of Pacific euphausiids. Bull. Scripps Instn. Oceanogr., $\underline{8}(2)$ : 51-269

1962b Two new species of Euphausiacea, Euphausia nana and Stylocheiron robustum from the Pacific. Crustaceana, $\underline{4}(3): 167-179$

DODIMEAD, A. J.

1961 Some features of the upper zone of the sub-Arctic Pacific Ocean. Int. N. Pacif. Fish. Comm., Bull. No. 3: 11-24

DODIMEAD, A. J., F. FAVORITE and T. HIRANO

1963 A review of the oceanography of the Subarctic Pacific region. Int. N. Pacif. Fish. Comm., Bull. No. 13: 1-195

FAVORITE, FELIX

1961 Surface temperature and salinity off the Washington and British Columbia coasts, August, 1958 and 1959. J. Fish. Res. Bd. Canada, 18(3): 311-319

FAVORITE, FELIX, RICHARD J. CALLAWAY and JAMES F. HEBARD

1961 North Pacific and Bering Sea oceanography, 1959. Spec. sci. Rep. U. S. Fish Wildl. Serv., Fish. No. 377: 1-116

FISHER, ROBERT L.

1961 Middle America Trench: topography and structure. Bull. Geol. Soc. Amer., 72(5): 703-720

HUBBS, C. L., and G. I. RODEN

Oceanography and marine life along the Pacific coast of Middle America. In Handbook of Middle American Indians. Middle Amer. Res. Inst., Tulane Univ., New Orleans, La. (in press)

ISAACS, JOHN D., and GEORGE B. SCHICK

1960 Deep-sea free instrument vehicle. Deep-Sea Res., $\underline{7}(1): 61-67$

KNAUSS, JOHN A.

1960a Equatorial currents. Trans. Amer. Geophys. Un., 41(2): 255-257

1960b Observations of irregular motion in the open ocean. Deep-Sea Res., $\underline{7}(1)$ : 68-69

1961 The structure of the Pacific equatorial countercurrent. J. Geophys. Res., 66(1): 143-155

1962 On some aspects of the deep circulation of the Pacific. J. Geophys. Res., $\underline{67}(10)$ : 39433954

LANE, R. K.

1962 A review of the temperature and salinity structures in the approaches to Vancouver Island, British Columbia. J. Fish. Res. Bd. Canada, 19(1): 45-91

MCALLISTER, C. D., T. R. PARSONS and J. D. H. STRICKLAND

1960 Primary productivity and fertility at Station "P" in the north-east Pacific Ocean. J. Cons. int. Explor. Mer, $\underline{25}(3)$ : 240-259

MCLAUGHLIN, PATSY A.

1963 Survey of the benthic invertebrate fauna of the eastern Bering Sea. Spec. sci. Rep. U. S. Fish Wildl. Serv., Fish. No. 401: 1-75

MUZINIC, R., and J. C. MARR

1960 Population identification. Proc. World Sci. Meeting Biol. Sardines and Related Species, 14-21 September 1959, Rome, Italy, Food and Agric., Unit. Nations, 1 (Rep.): 3-6

REID, JOSEPH L., JR.

1962a Distribution of dissolved oxygen in the summer thermocline. J. Mar. Res., 20(2): 138-148

1962b On the circulation, phosphate-phosphorus content and zooplankton volumes in the upper part of the Pacific Ocean. Limnol. Oceanogr., 7(3): 287-306 On the formation and circulation of the Intermediate Water in the North and South Pacific oceans. (in press)

REID, JOSEPH L., JR., and RICHARD A. SCHWARTZLOSE

1962 Direct measurements of the Davidson Current off Central California. J. Geophys. Res., $\underline{67}(6): 2491-2497$ 
REID, JOSEPH L., JR., R. A. SCHWARTZLOSE and D. M. BROWN

1964 Direct measurements of a small eddy off northern Baja California. J. Mar. Res., 21(3): 205-218

RODEN, G. I.

1963 On sea level, temperature and salinity variations in the tropical Pacific and in Pacific Ocean islands. J. Geophys. Res., 68(2): 455-472 Marine geology of the Gulf of California. Bull. Amer. Ass. Petrol. Geol. (in press) Oceanographic aspects of the Gulf of California. In Gulf of California, Amer. Ass. Petrol. Geol. (in press)

SCHICK, GEORGE B., and JOHN D. ISAACS

1961 Underwater remote programming. Undersea Tech., 1961(6): 29-32

SCHWARTZLOSE, RICHARD A.

1963 Nearshore currents of the western United States and Baja California as measured by drift bottles. In Calif. Cooperative Fish. Invest., Reps., 1 July 1960 to 30 June 1962, Mar. Res. Comm., 9: 15-22

THRAILKILL, JAMES R.

1961 Zooplankton volumes off the Pacific coast, 1958. Spec. sci. Rep. U. S. Fish Wildl. Serv., Fish. No. 374: 1-70

VON HERZEN, RICHARD P.

1963 Geothermal heat flow in the Gulfs of California and Aden. Science, 140(3572): 1207-1208

WYLLIE, JOHN G.

1961 The water masses of Sebastian Vizcaino Bay. In Calif. Cooperative Fish. Invest., Reps. 1 July 1959 to 30 June 1960, Mar. Res. Comm., 8 : 83-93

WYRTKI, KLAUS

Upwelling in the Costa Rica Dome. Fish. Bull., U. S. (in press) 


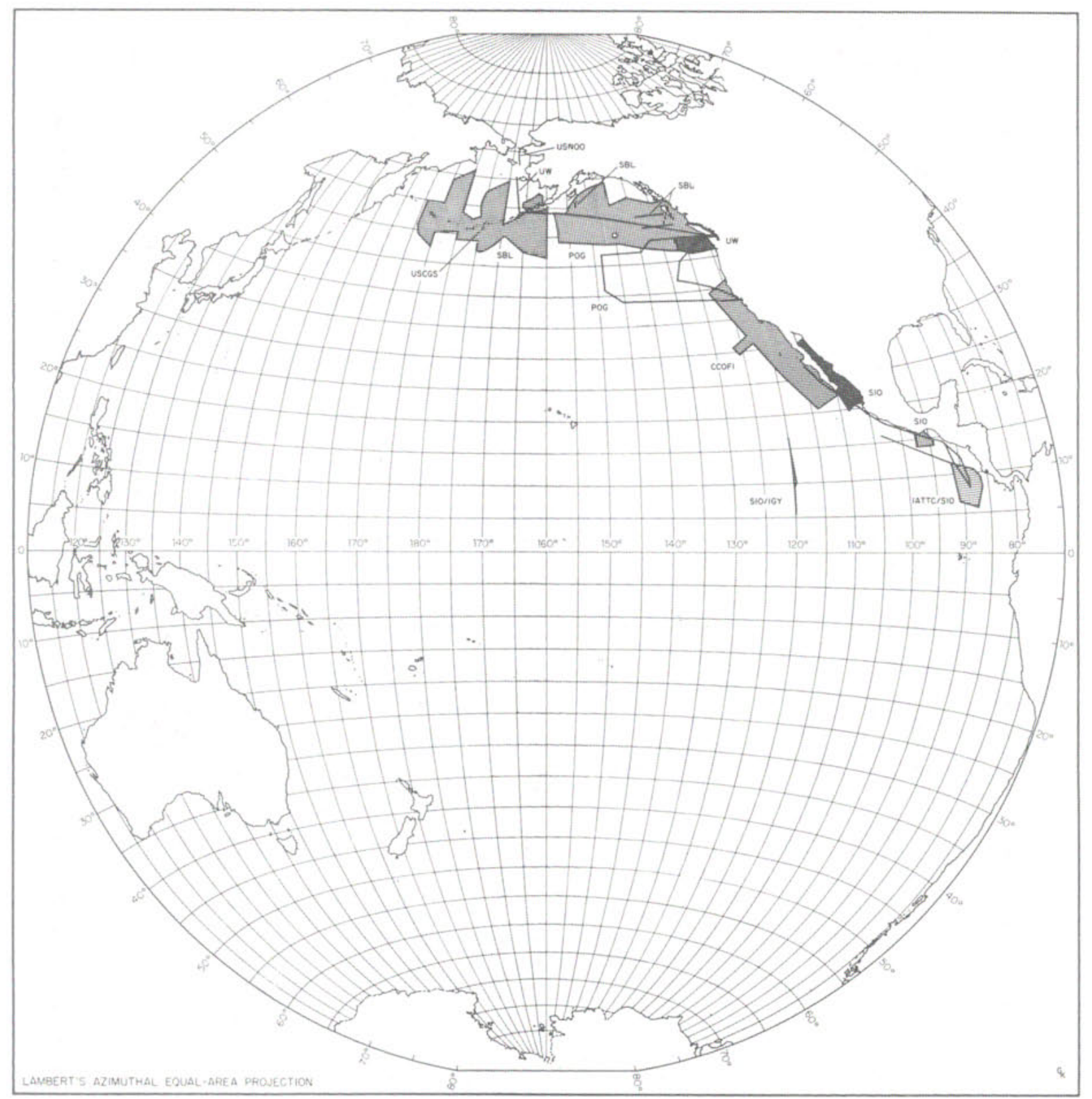

CHART 1. General location chart 

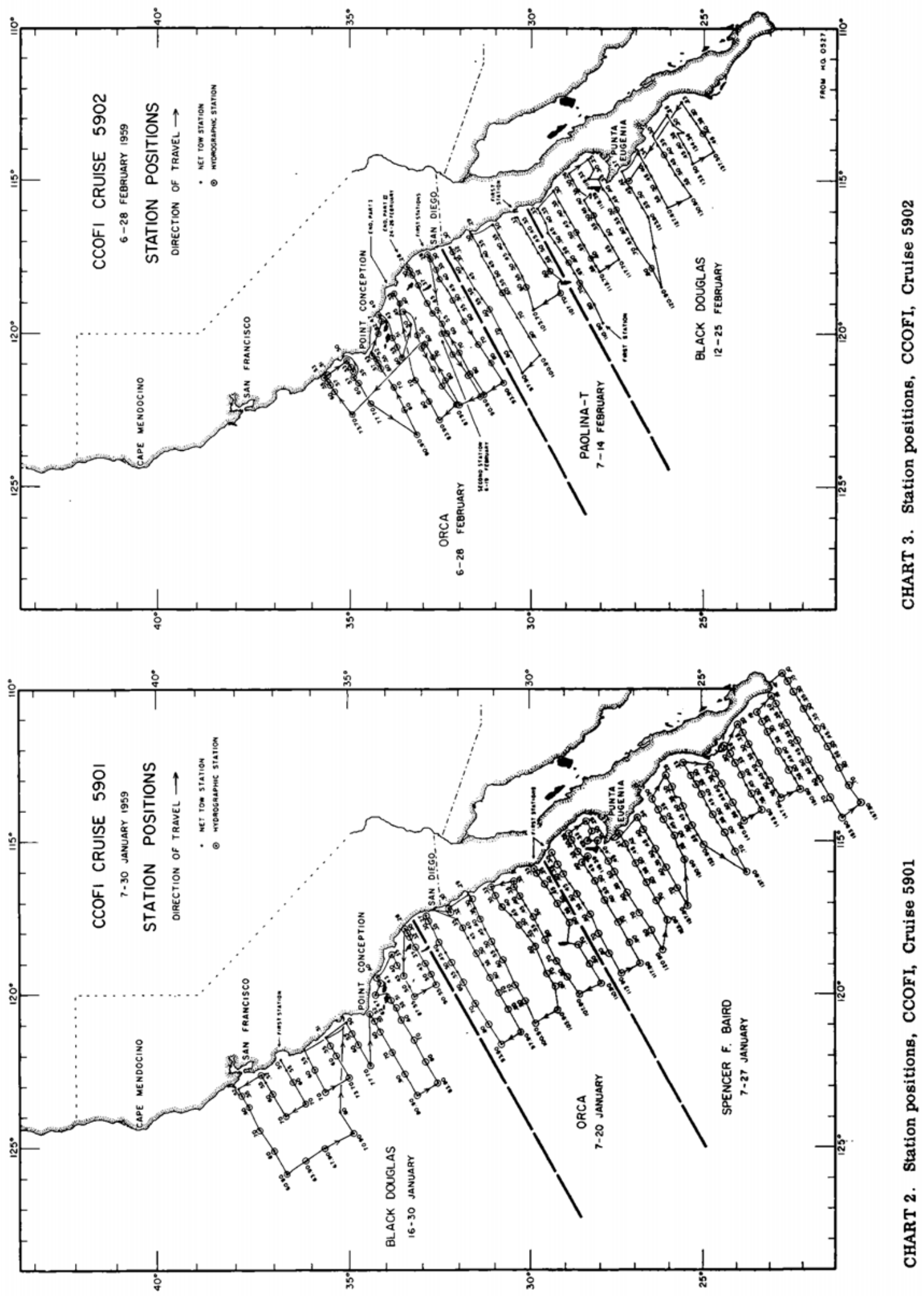

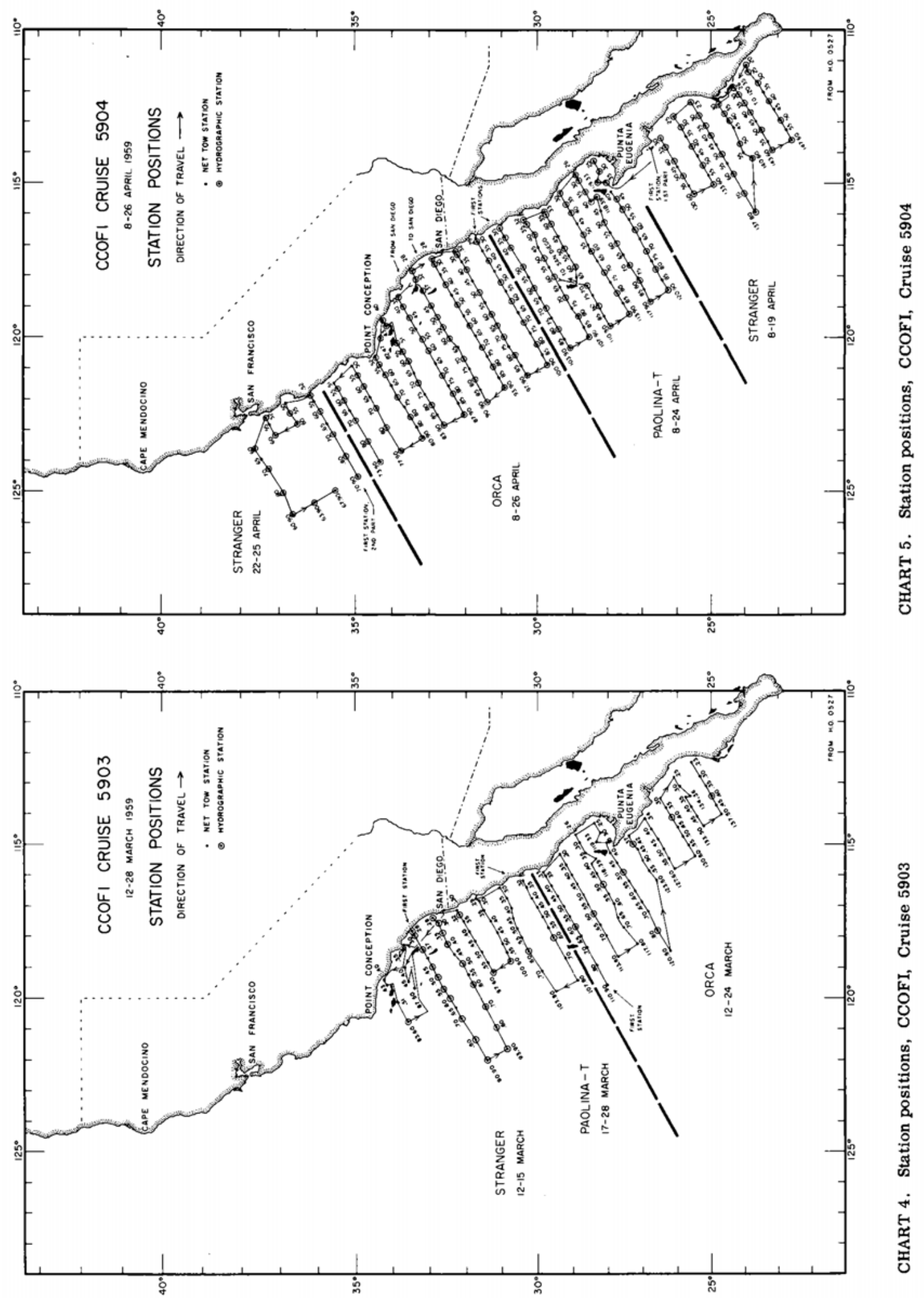

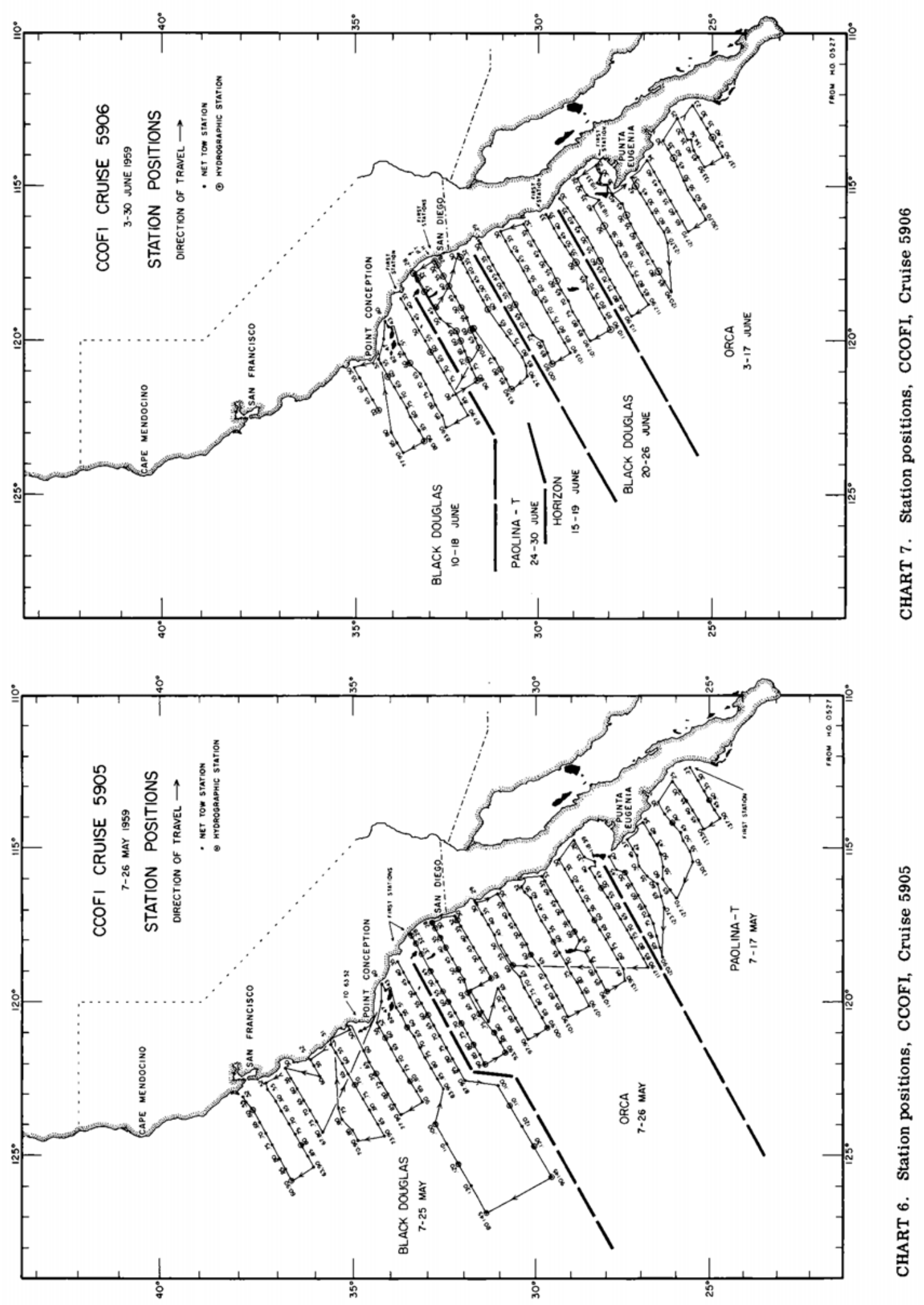

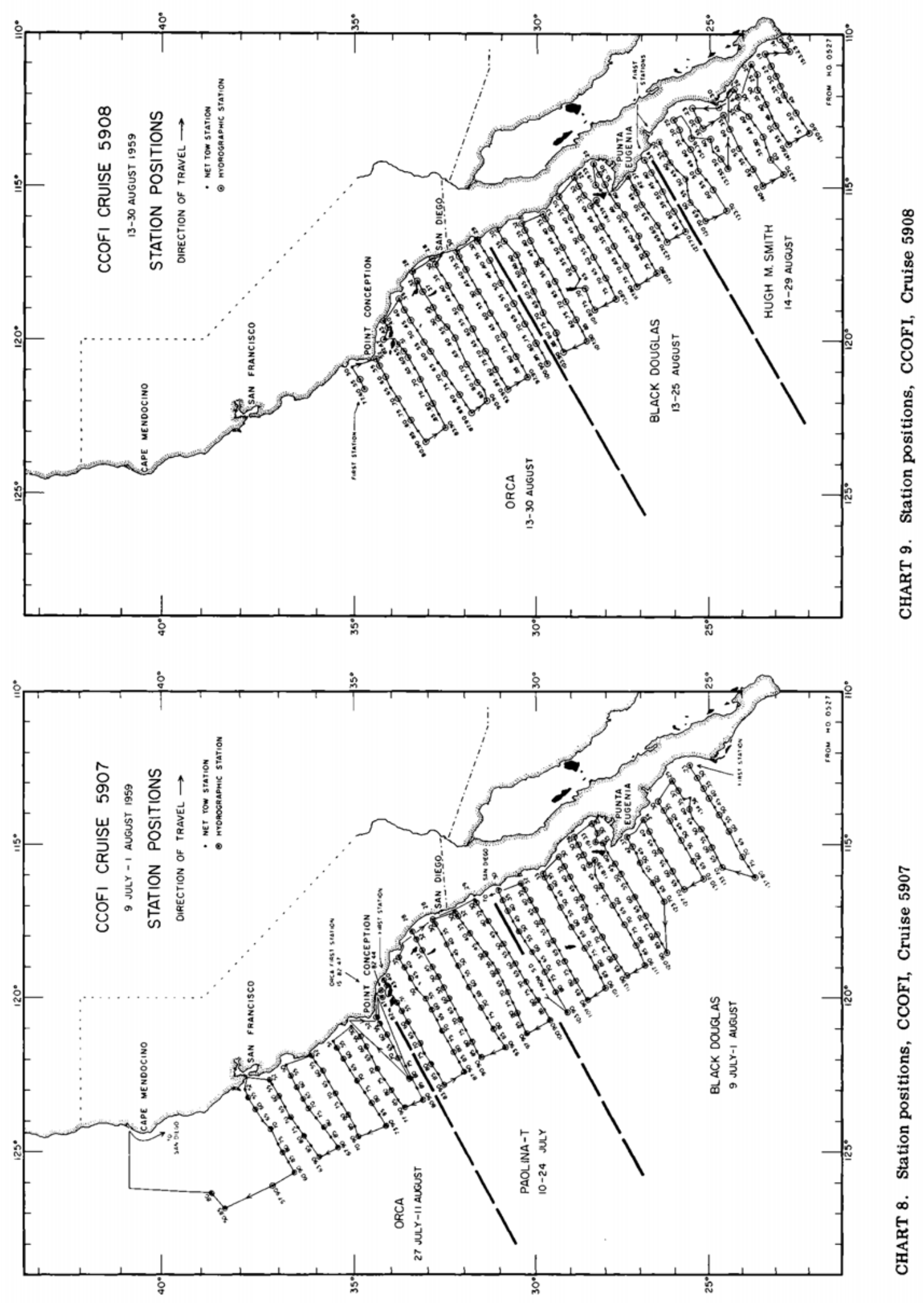

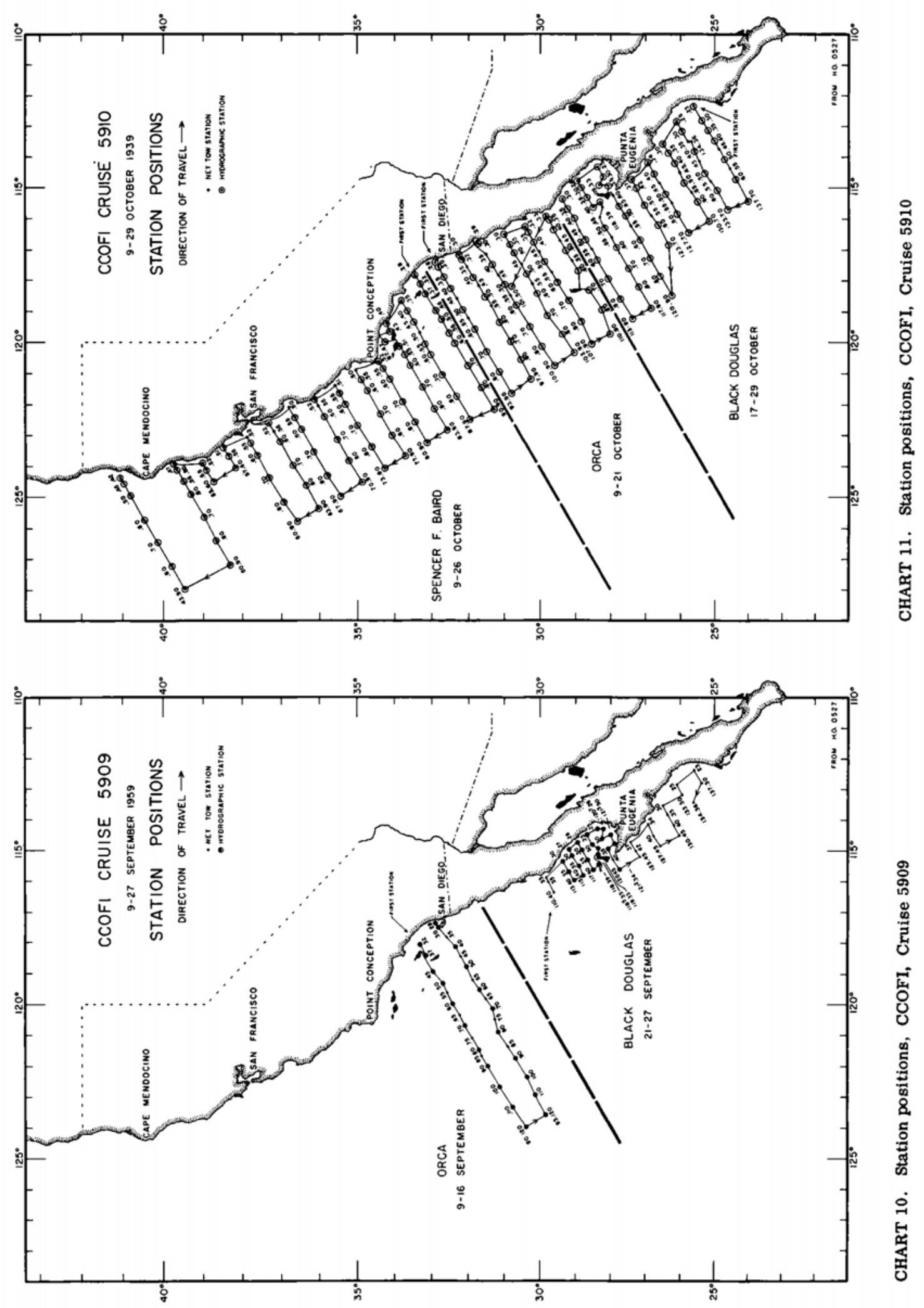

웅 

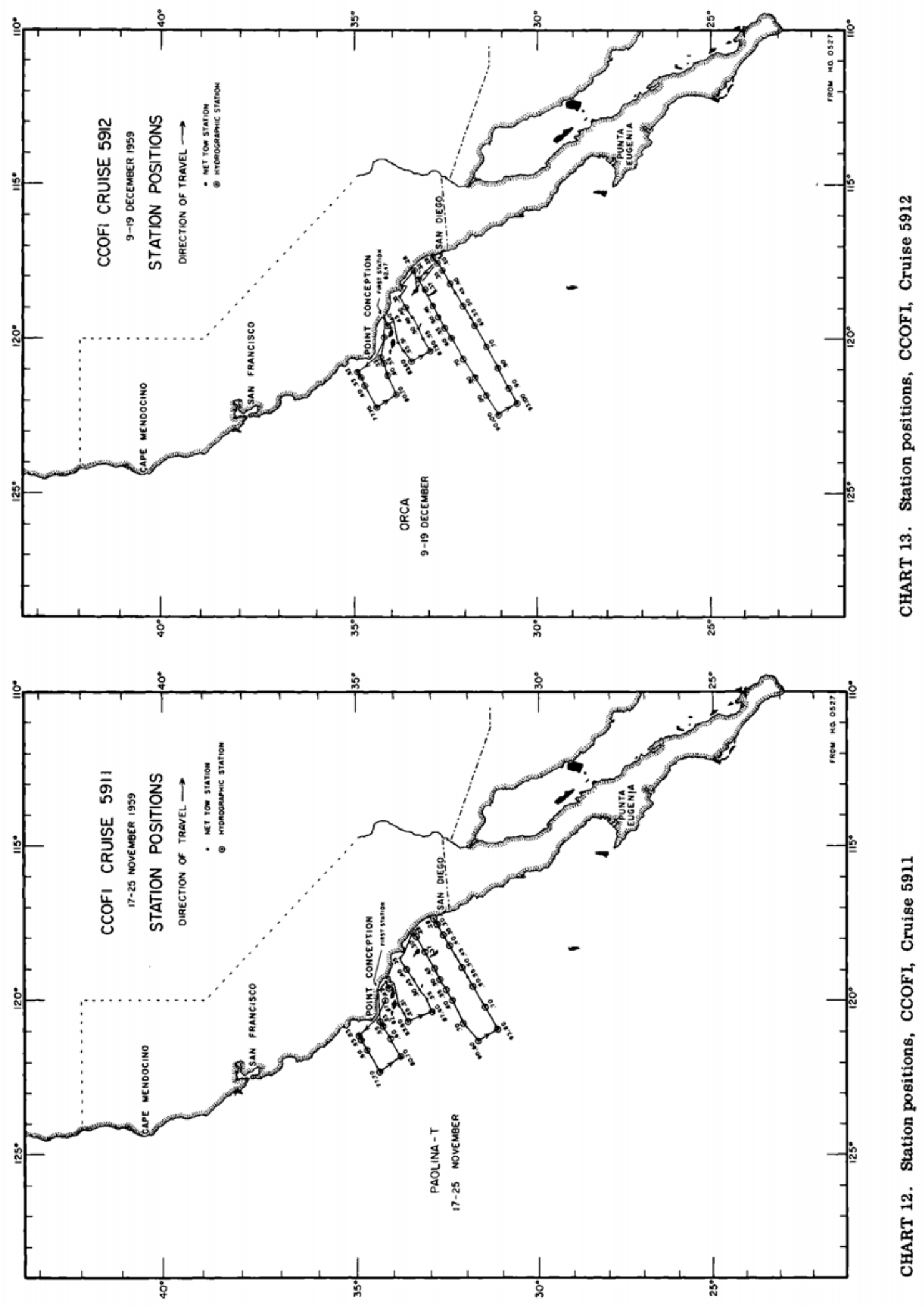


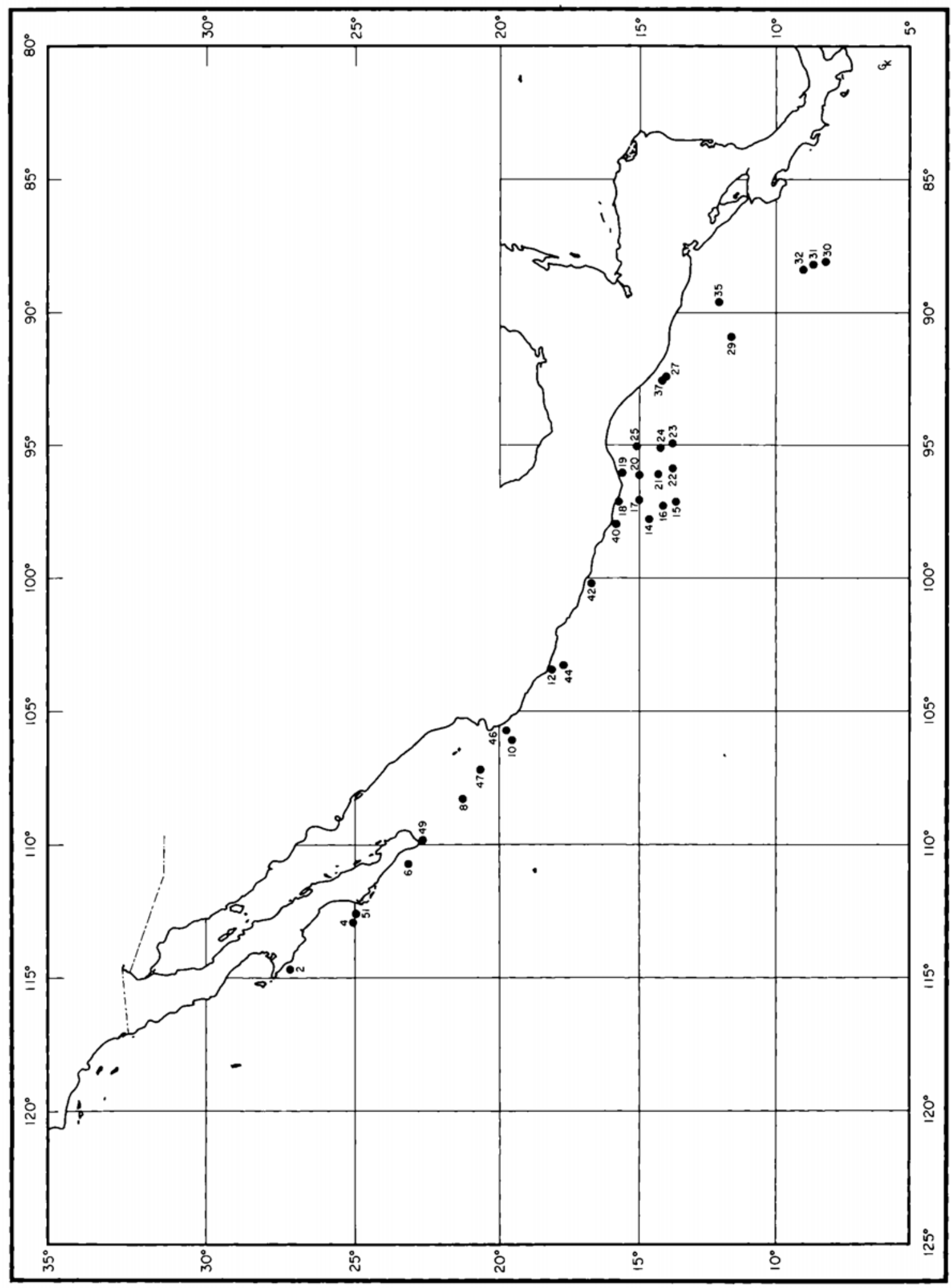

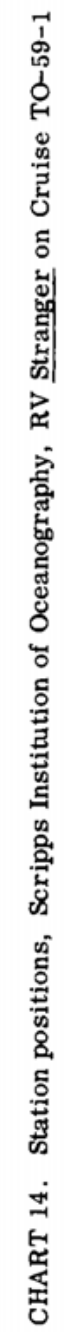




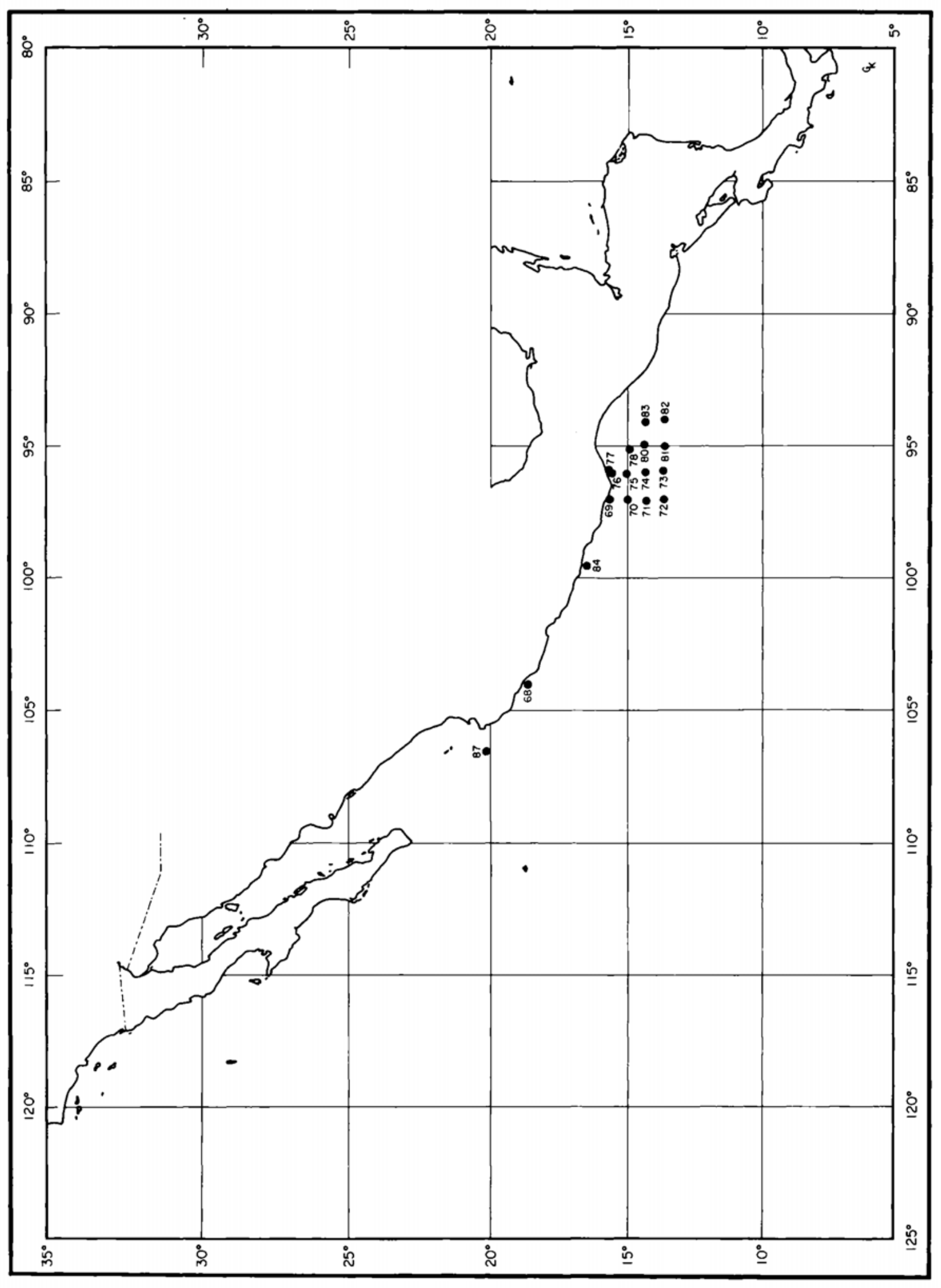

| 


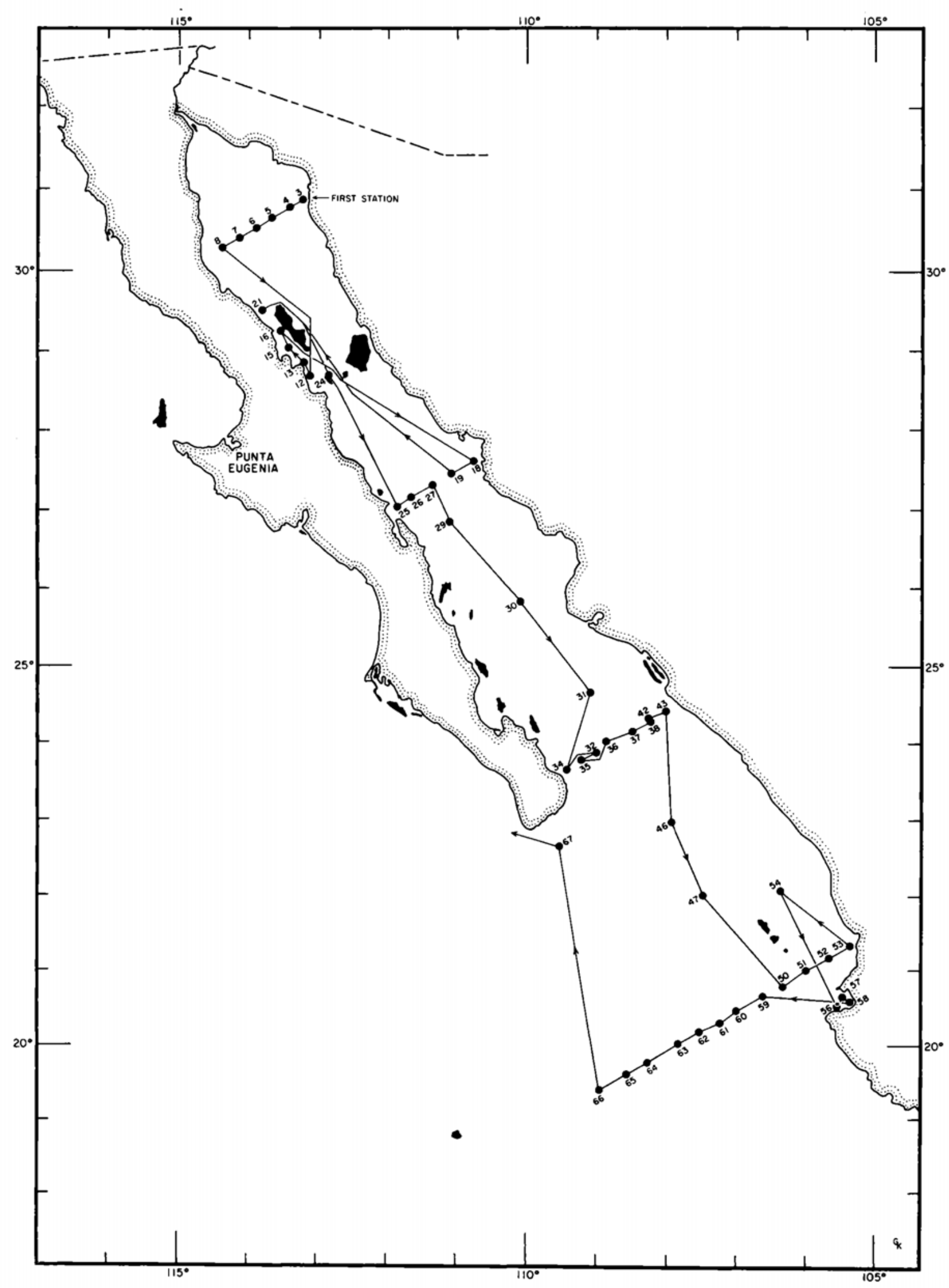

CHART 16. Station positions, Scripps Institution of Oceanography, RV Spencer $\underline{\text { F }}$. Baird on Expedition Vermilion Sea

xxxviii 


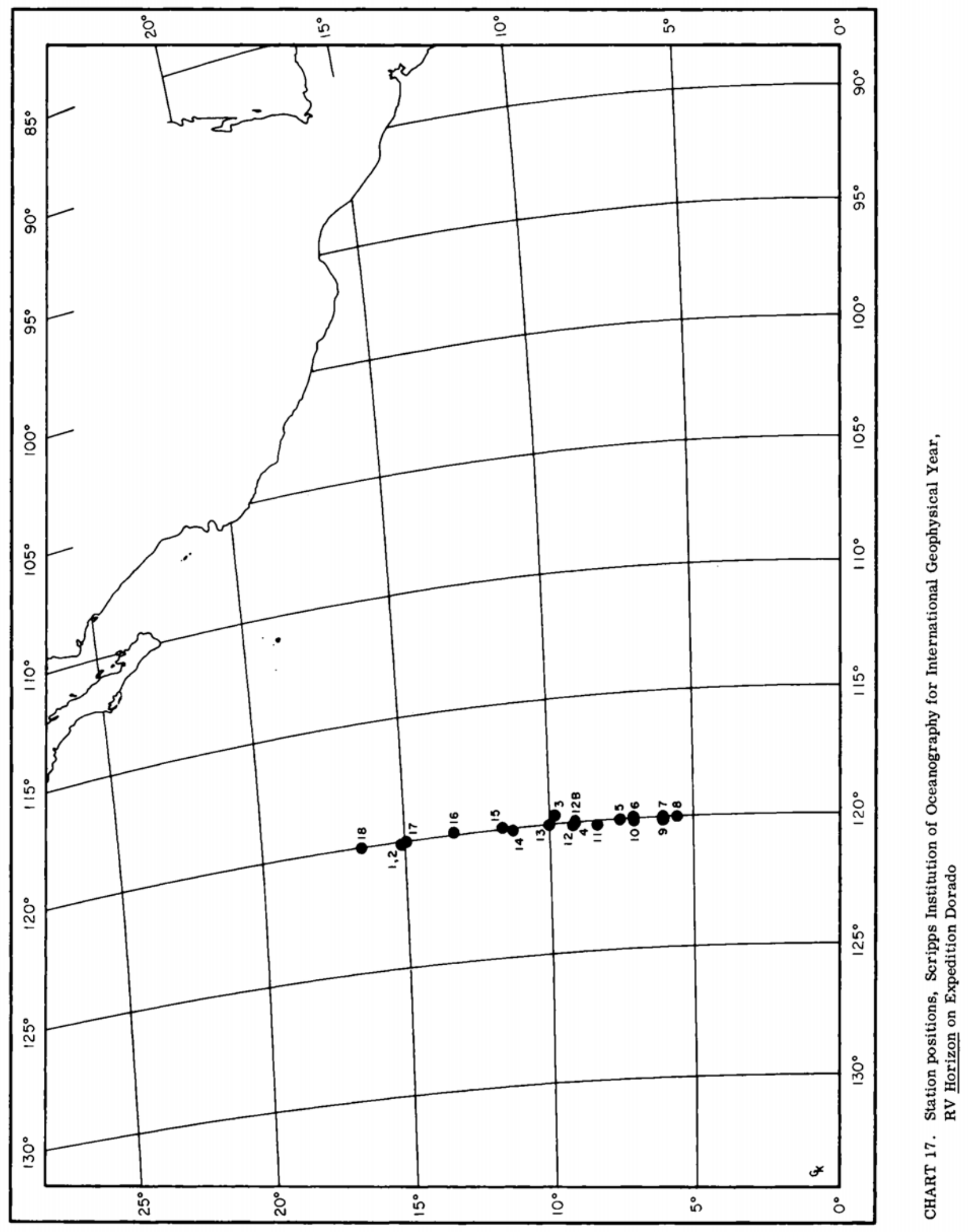

xxxix 


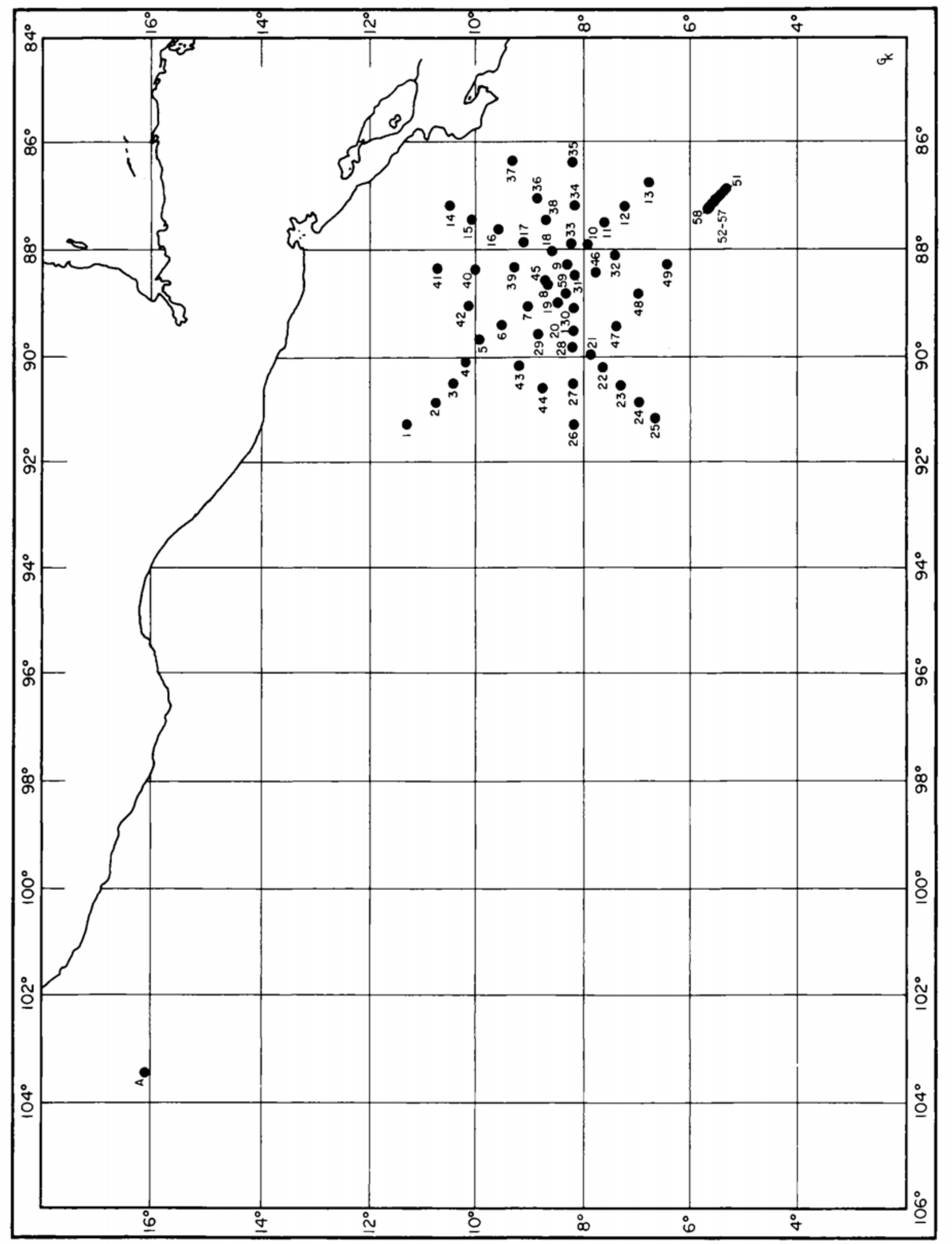

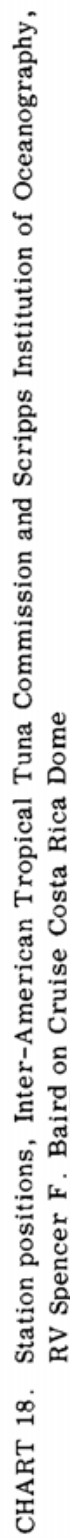




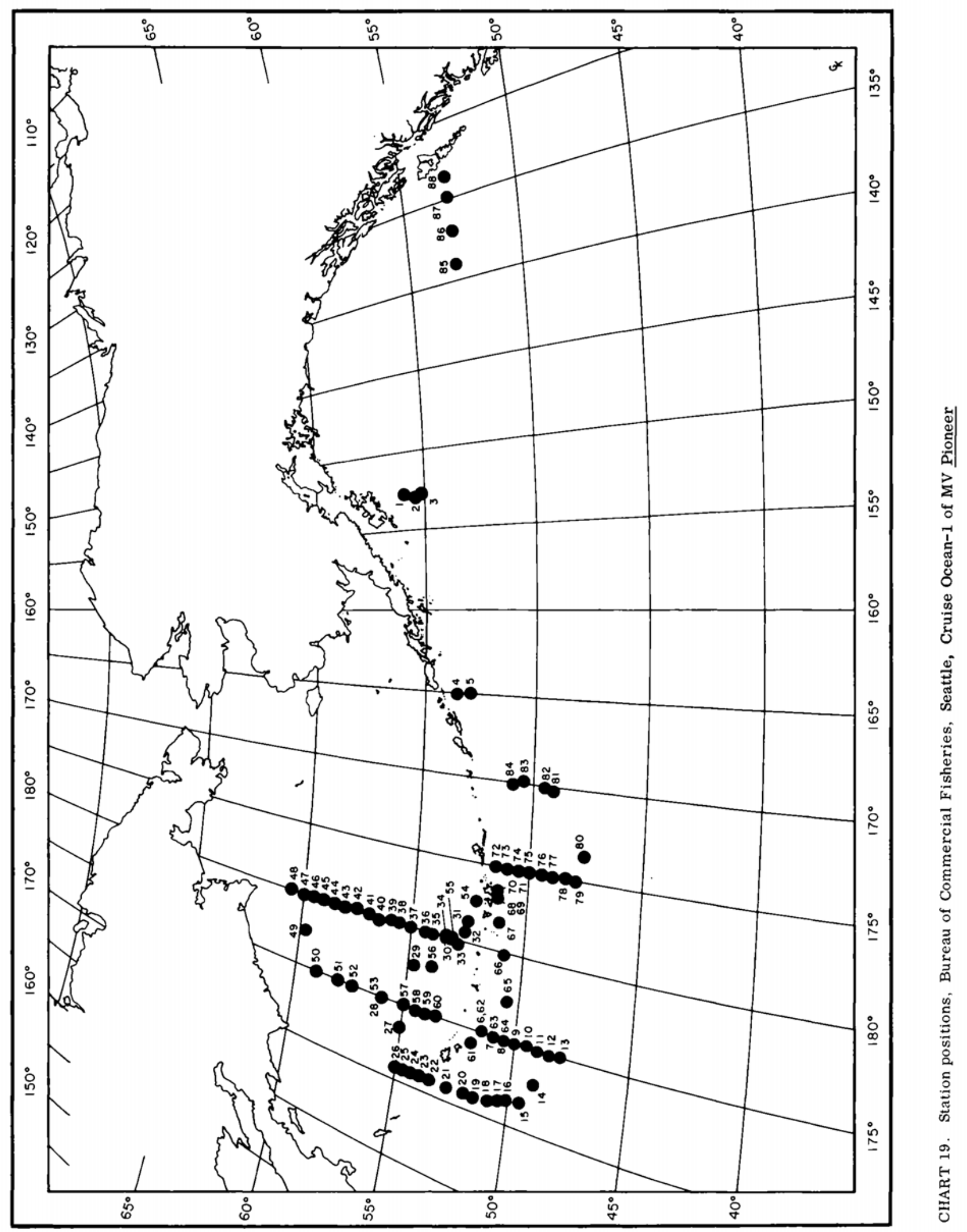




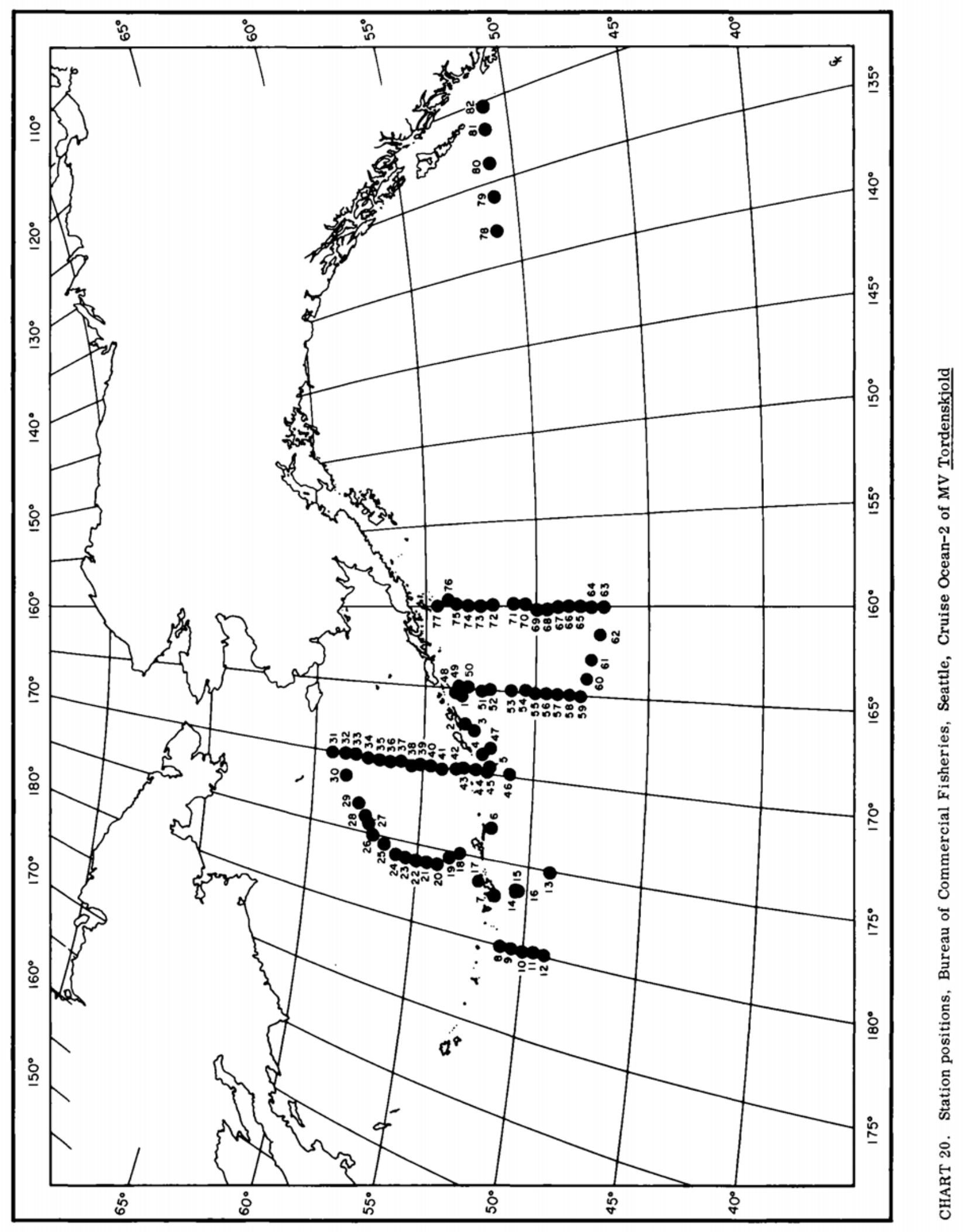




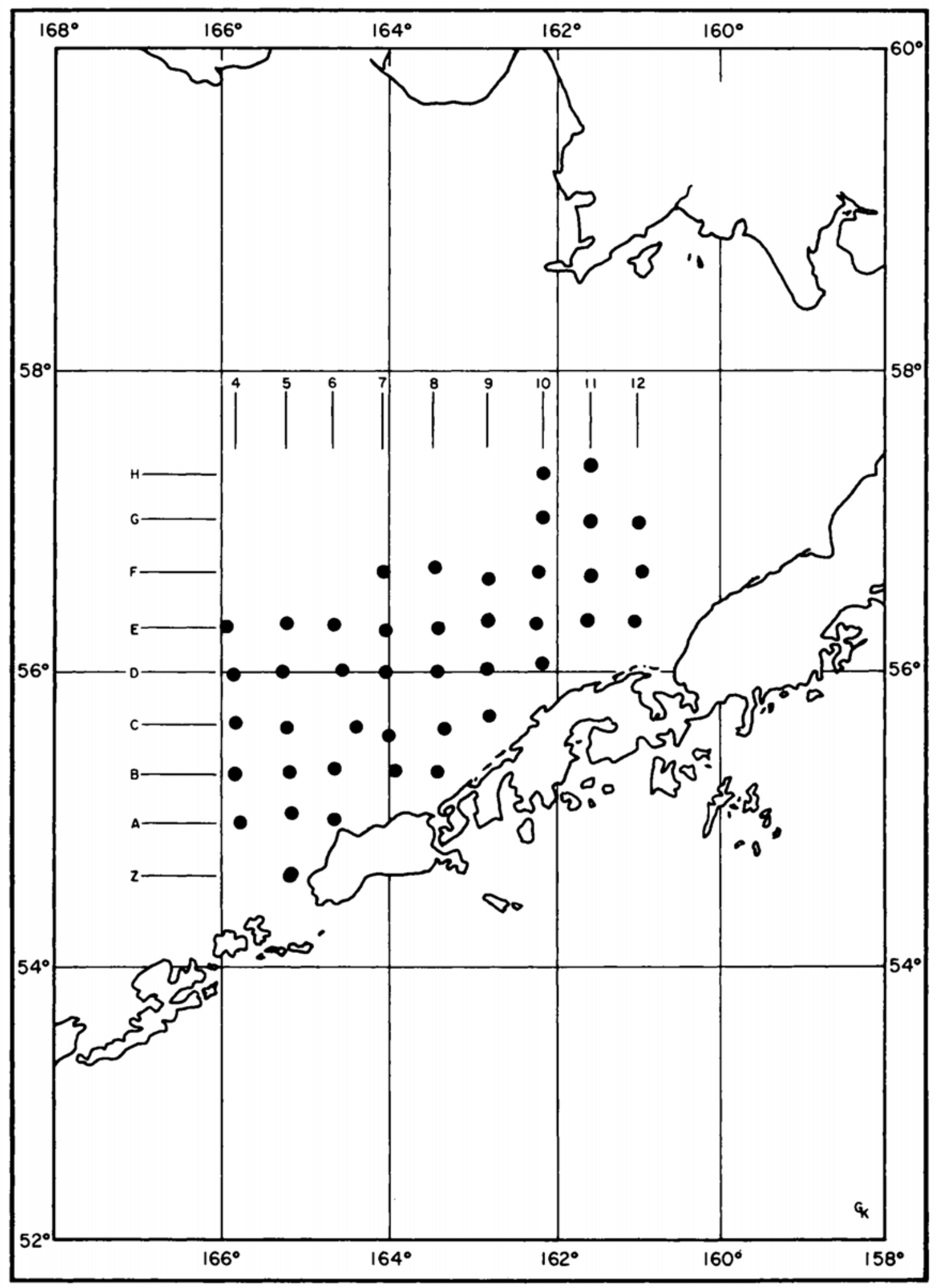

CHART 21. Station positions, Bureau of Commercial Fisheries, Seattle, King Crab Investigations, MV Tordenskjold 


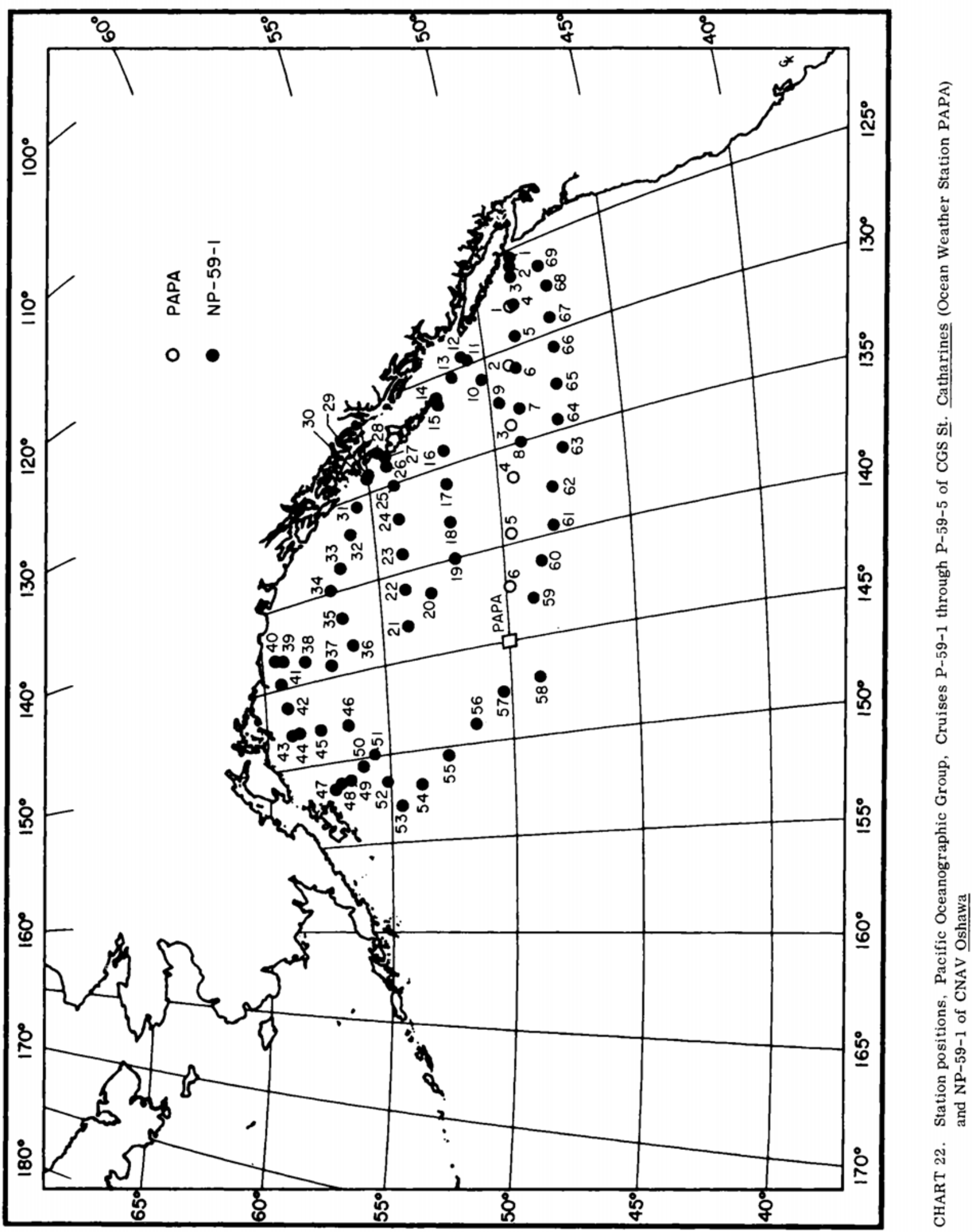




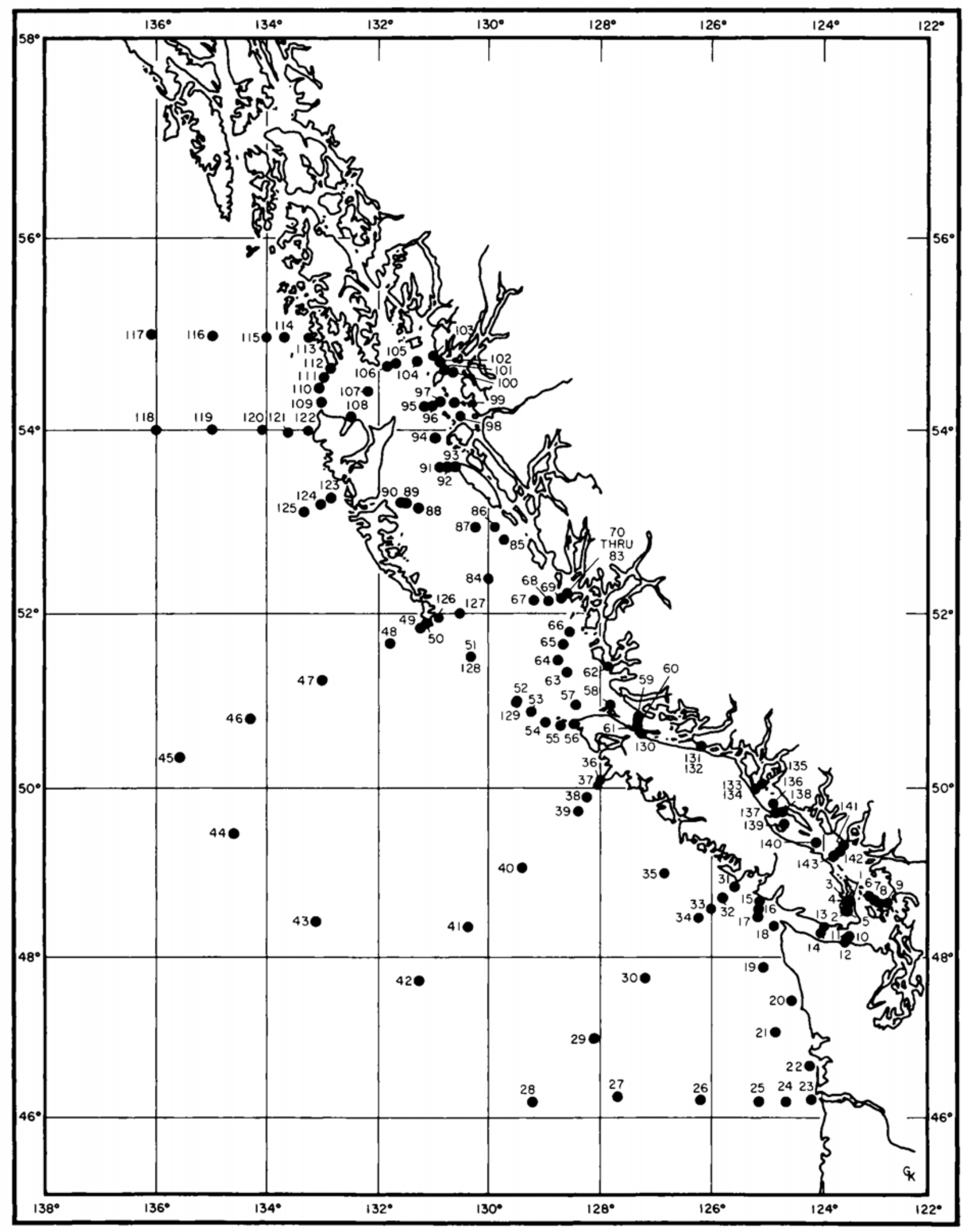

CHART 23. Station positions, Pacific Oceanographic Group, Cruise CS-59-1 of CNAV Oshawa 


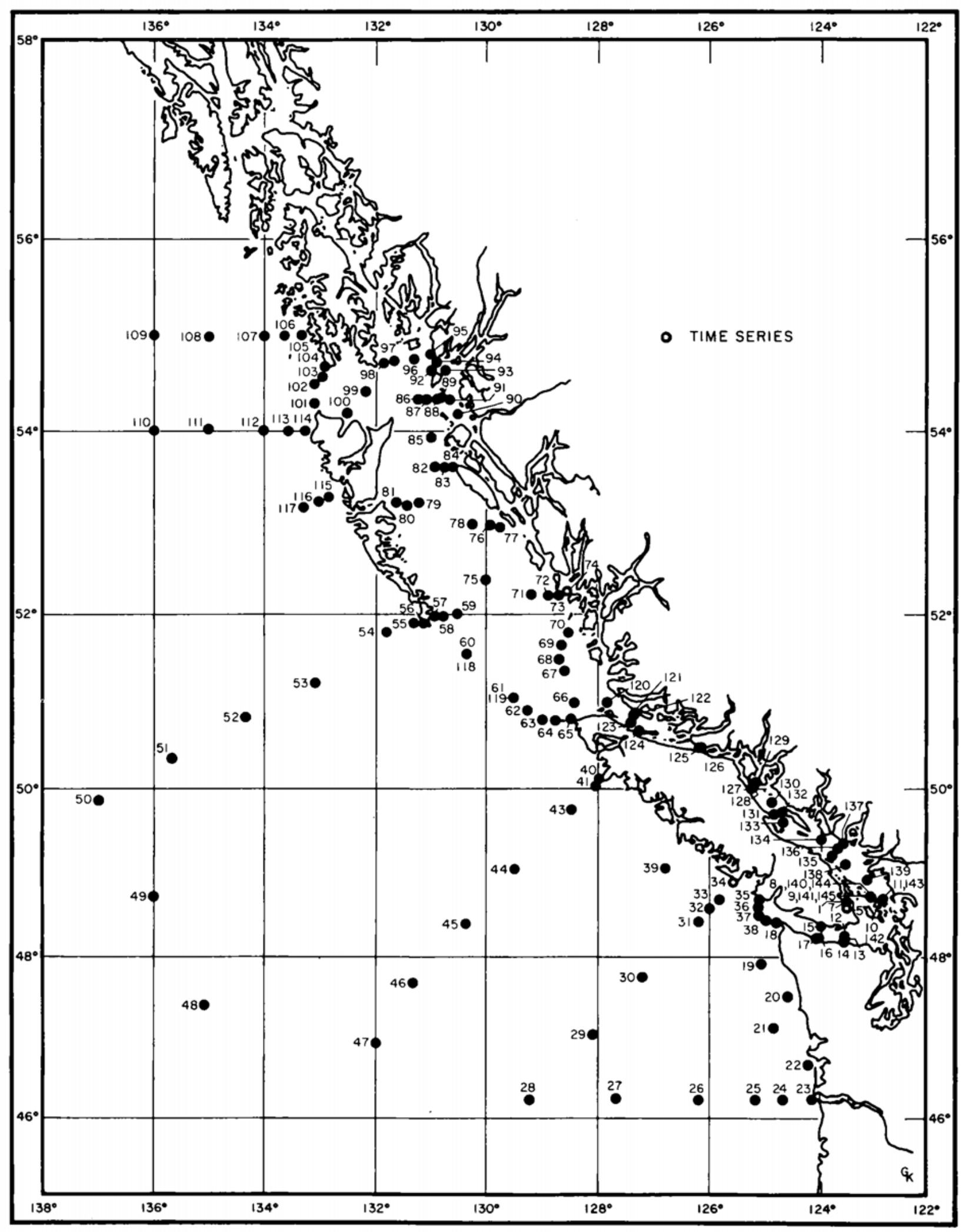

CHART 24. Station positions, Pacific Oceanographic Group, Cruise CS-59-2 of CNAV Oshawa 


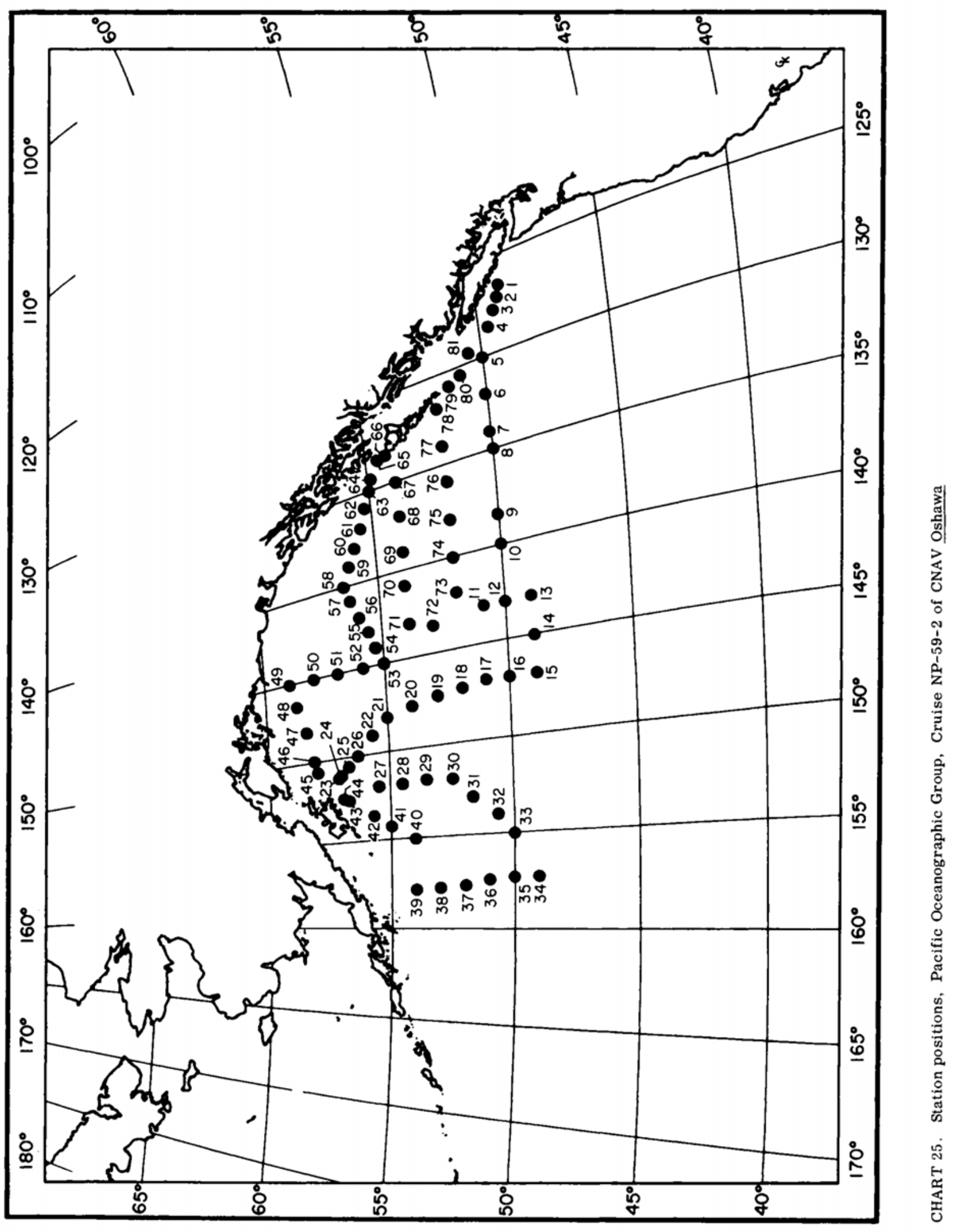




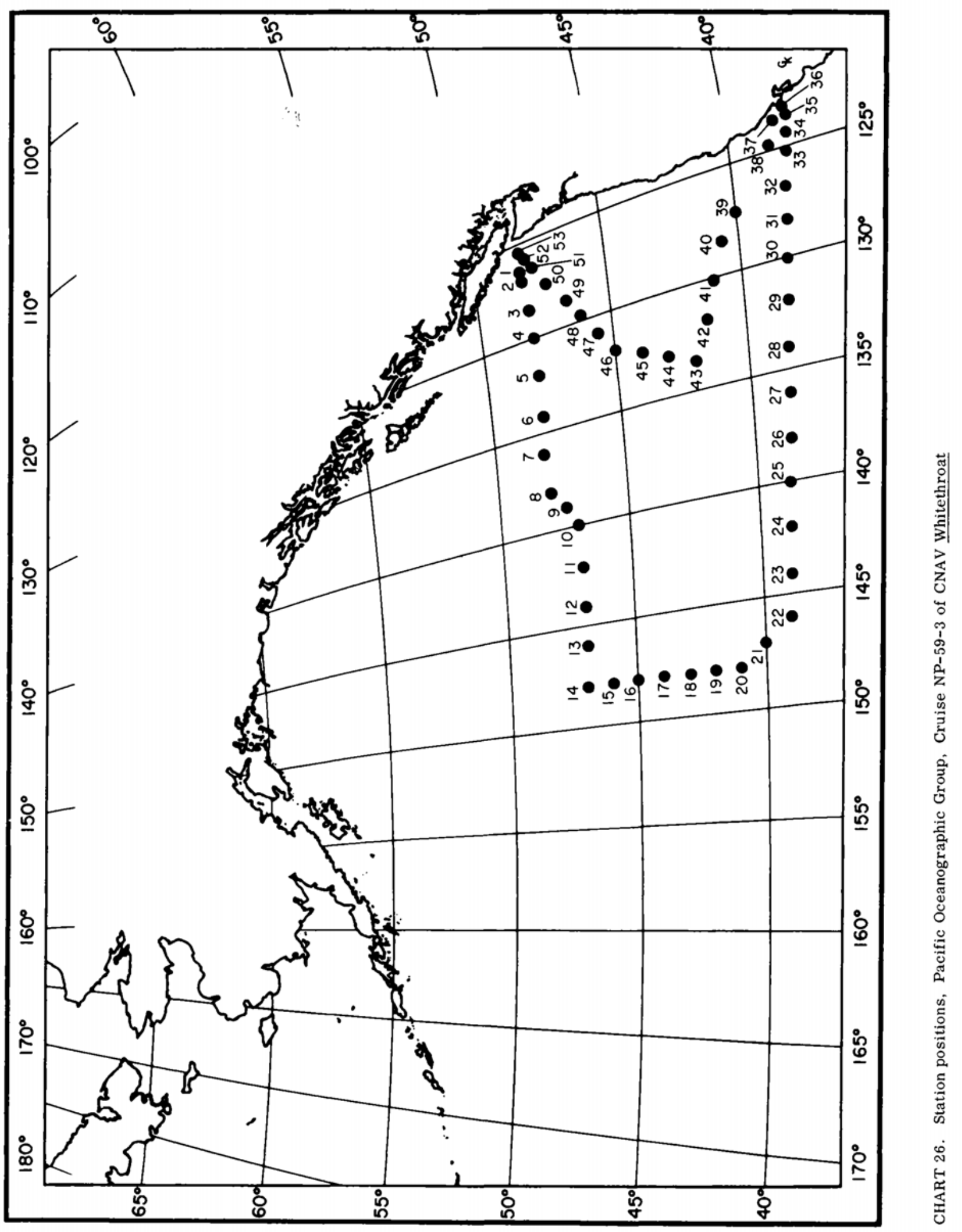




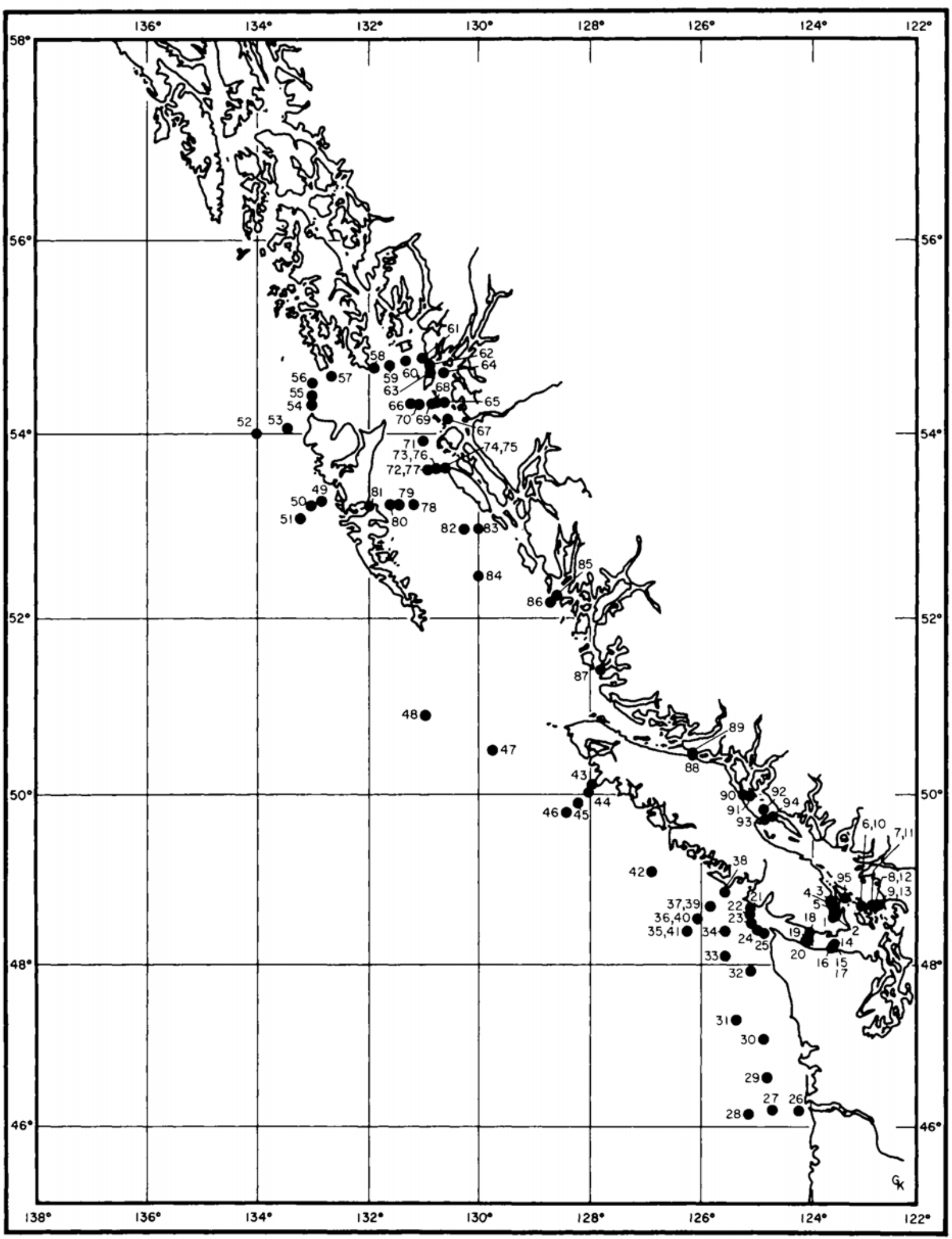

CHART 27. Station positions, Pacific Oceanographic Group, Cruise CS-59-3 of CNAV Oshawa 


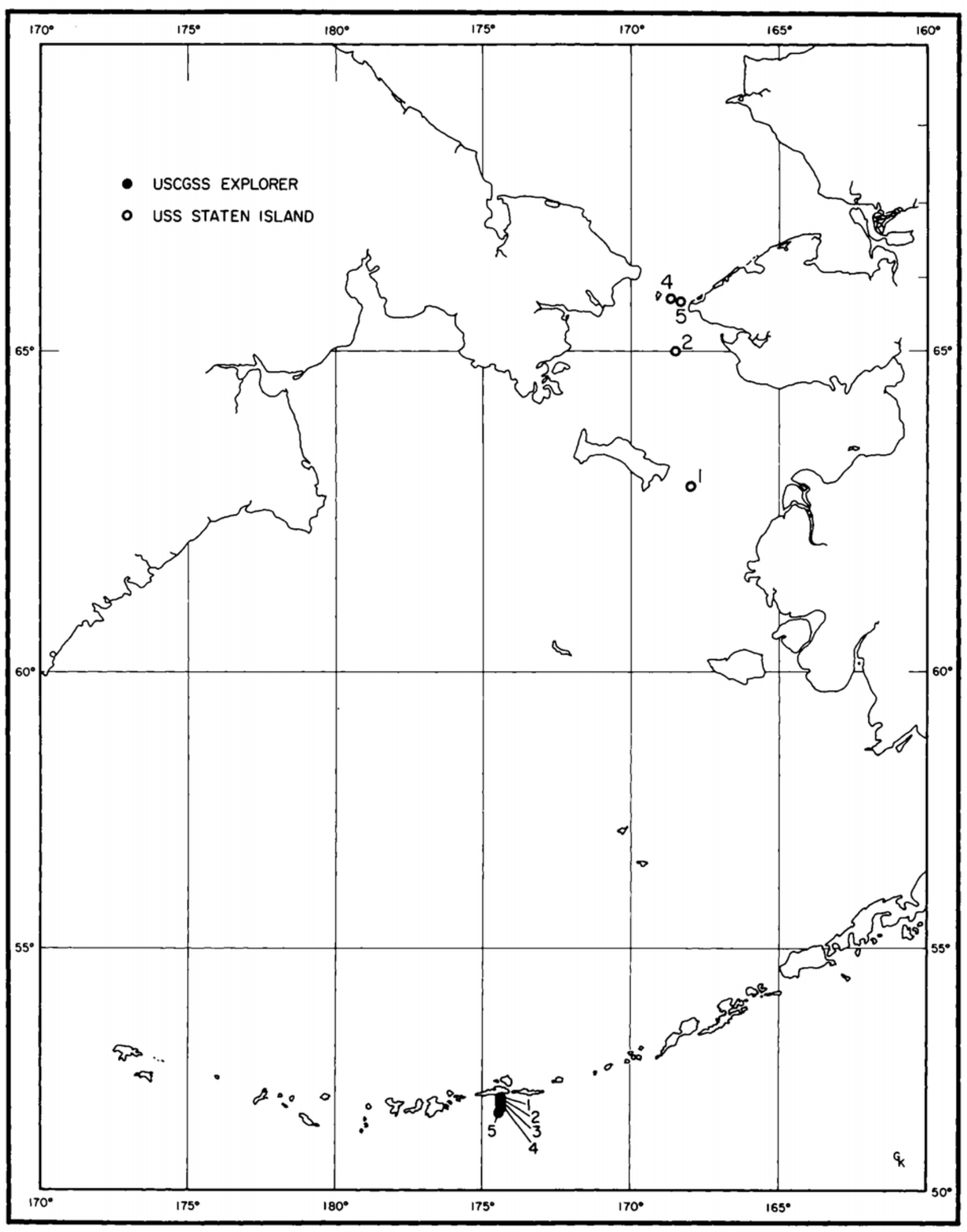

CHART 28. Station positions, U. S. Coast and Geodetic Survey, USCGSS Explorer, and U. S. Naval Oceanographic Office, USS Staten Island 


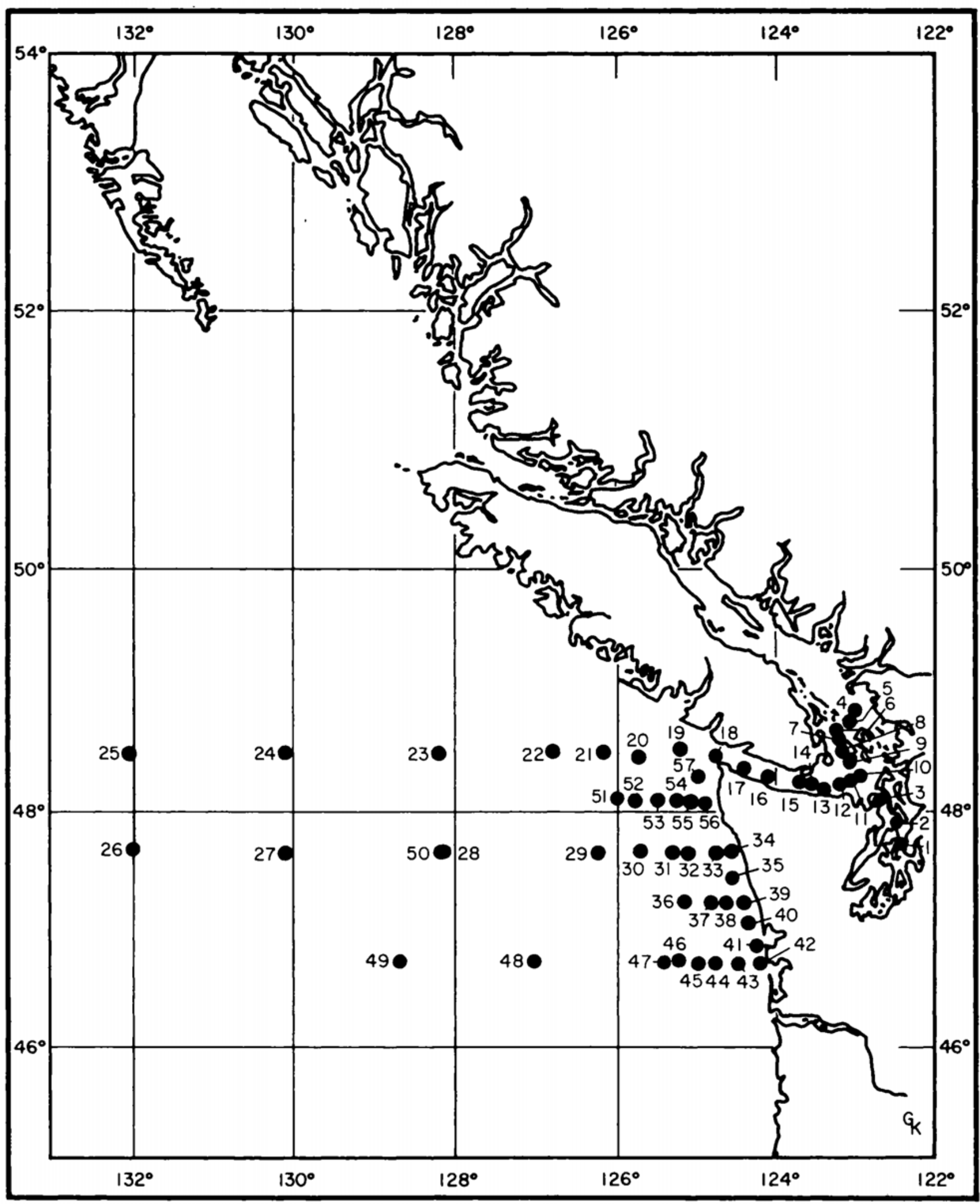

CHART 29. Station positions, University of Washington, Cruise 234 of RV Brown Bear 


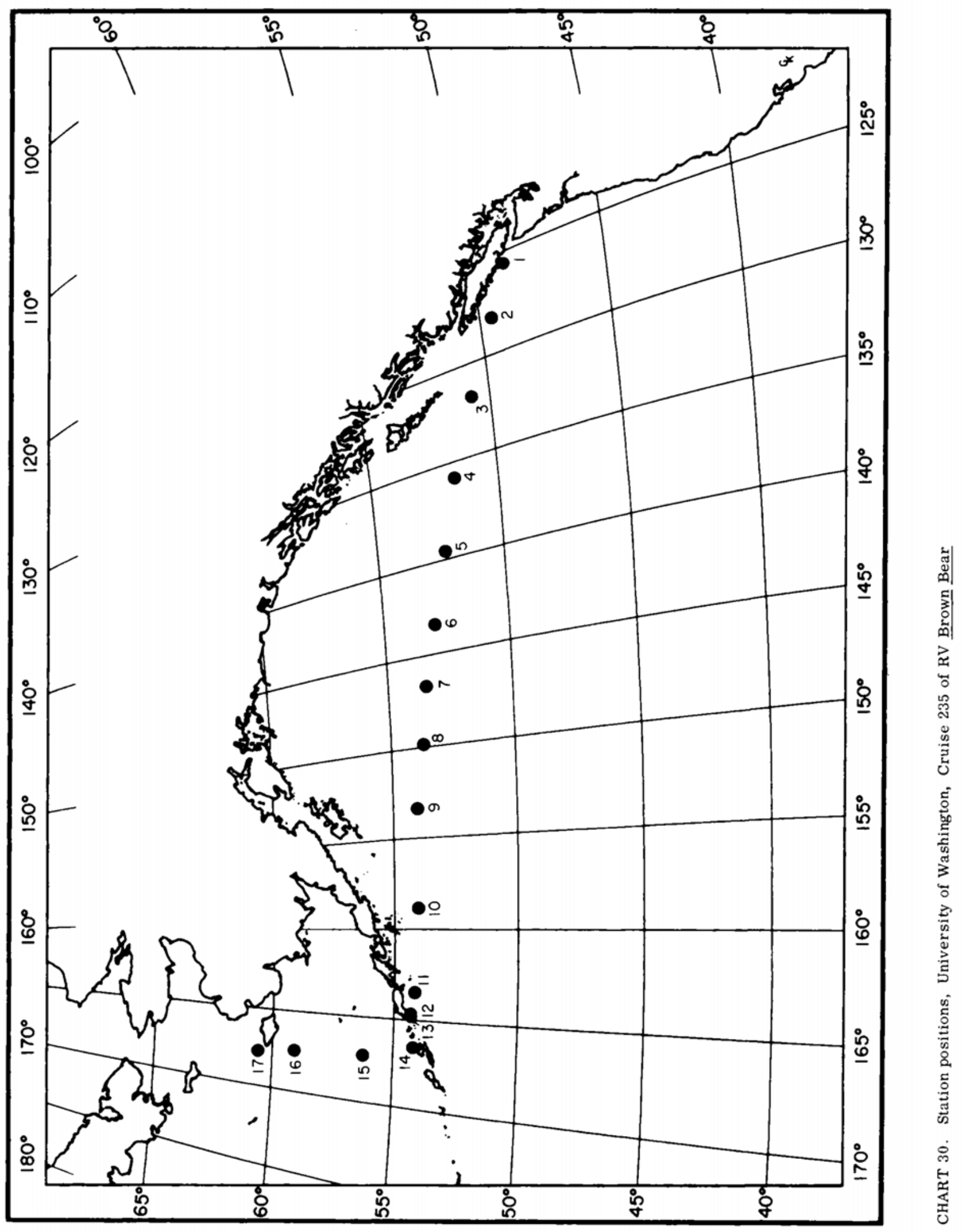




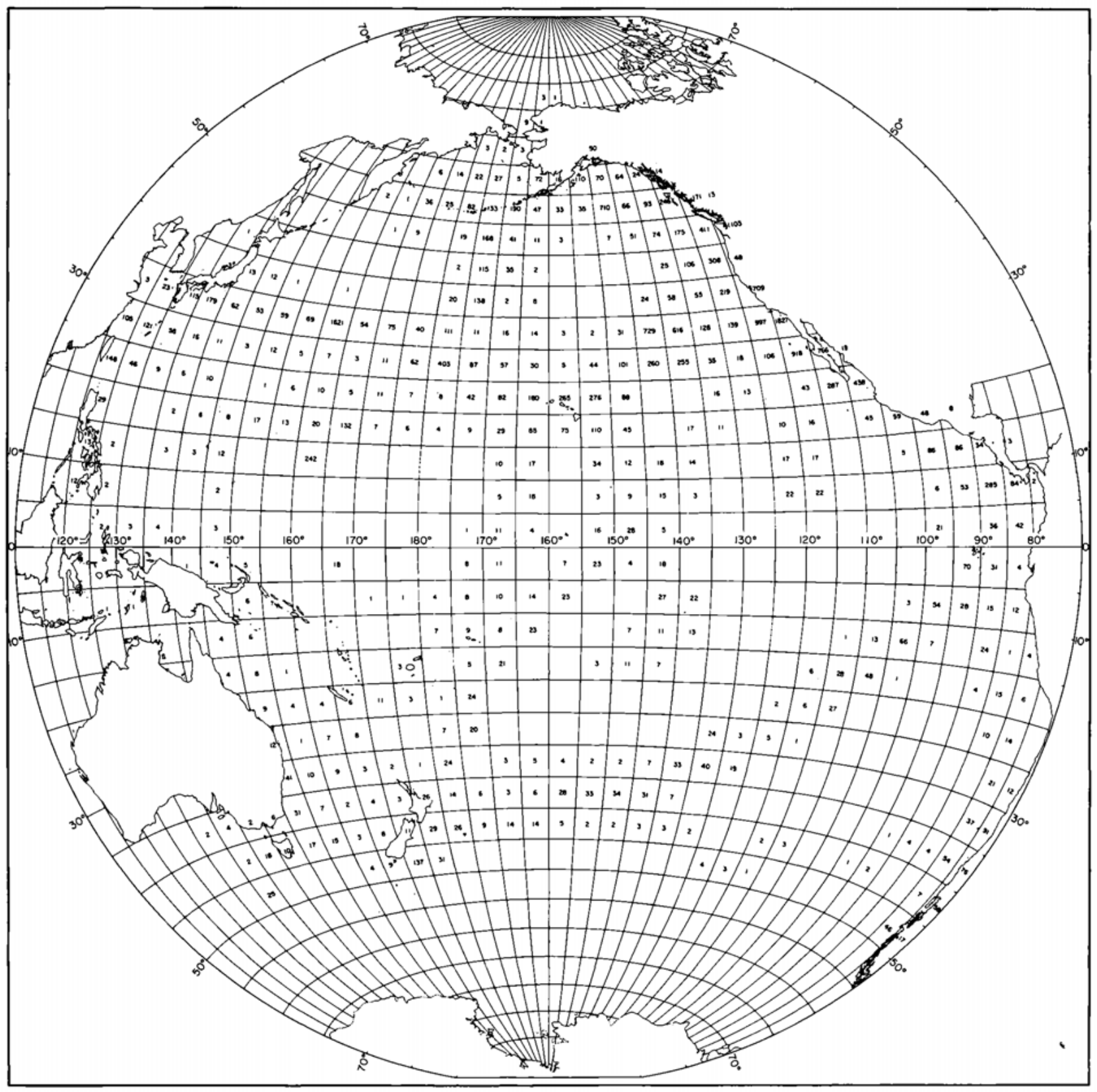

CHART 31. Bathythermograph observations, North and South Pacific, 1959; total, 23, 457 


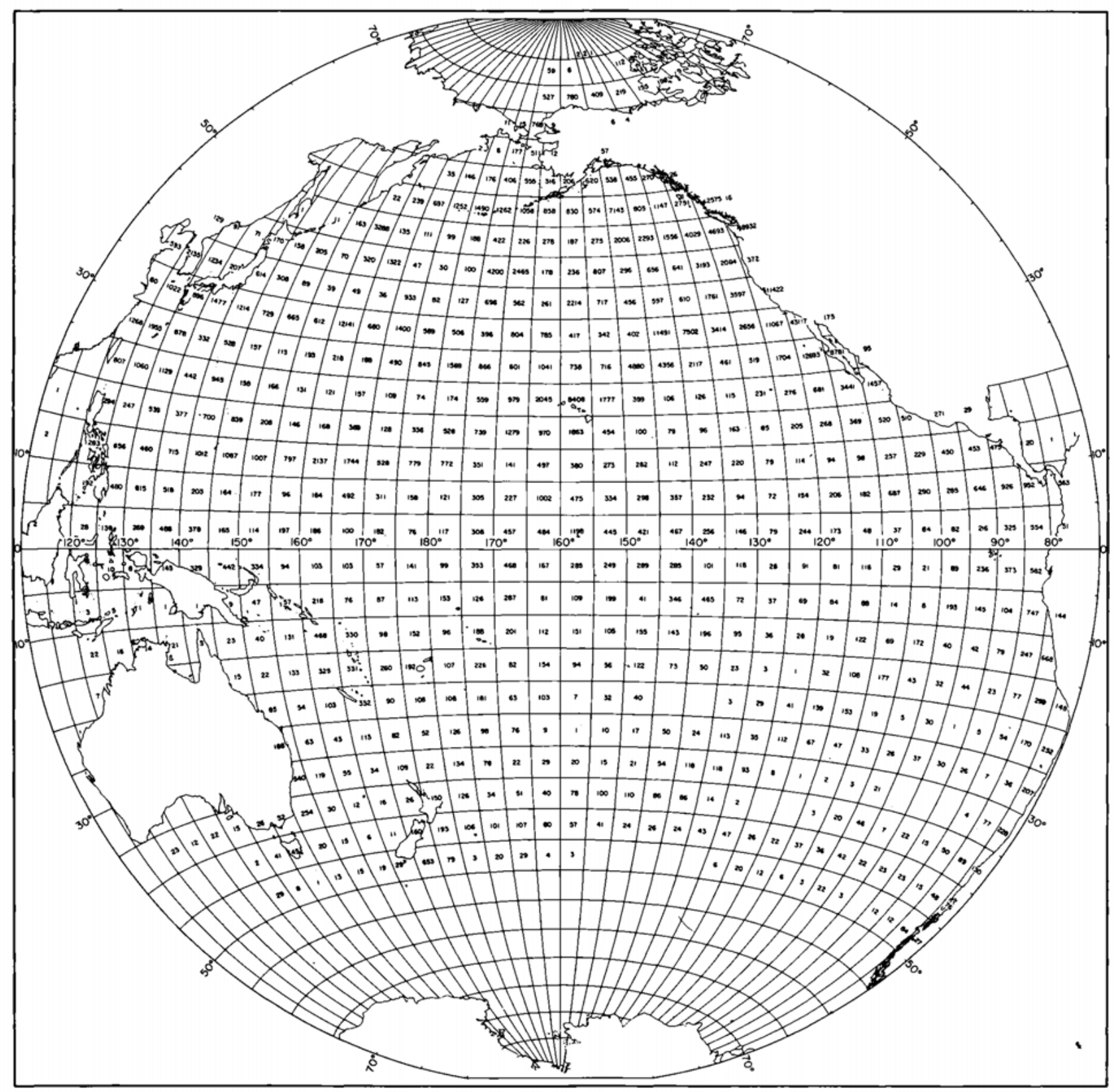

CHART 32. Bathythermograph observations, North and South Pacific, 1941-1959; total, 356,604 


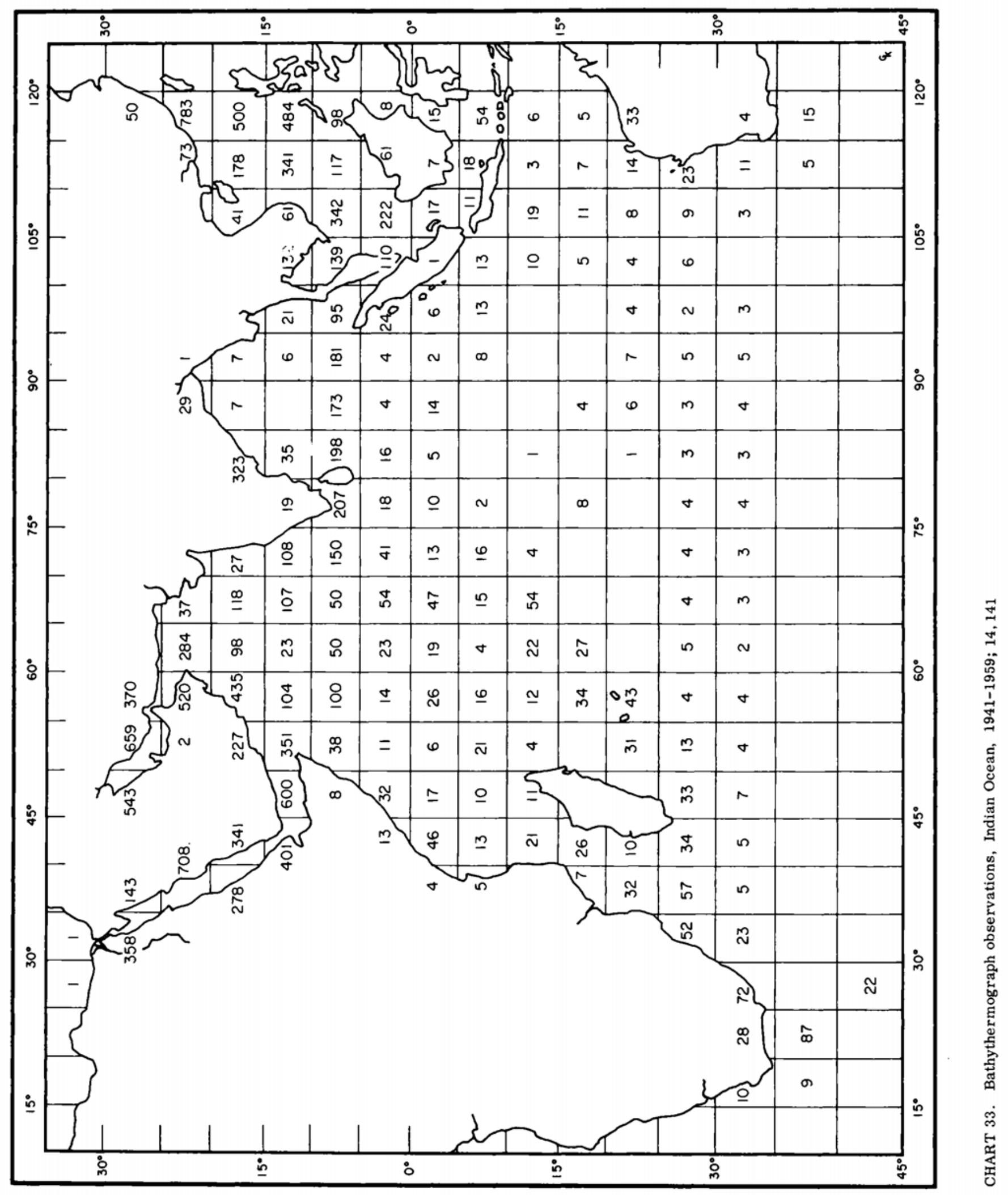




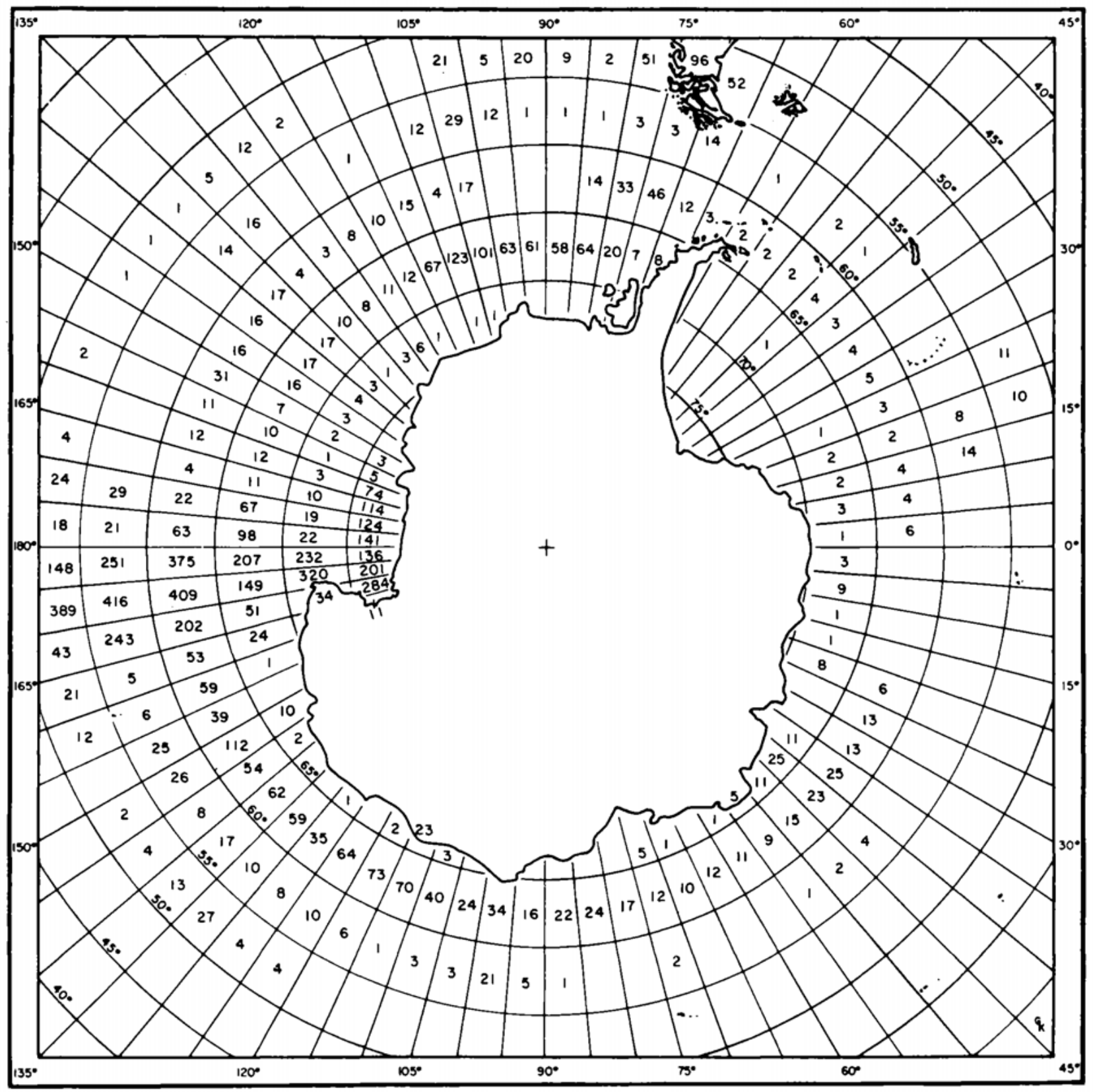

CHART 34. Bathythermograph observations, Antarctic Ocean, 1941-1959; total, 7,848 


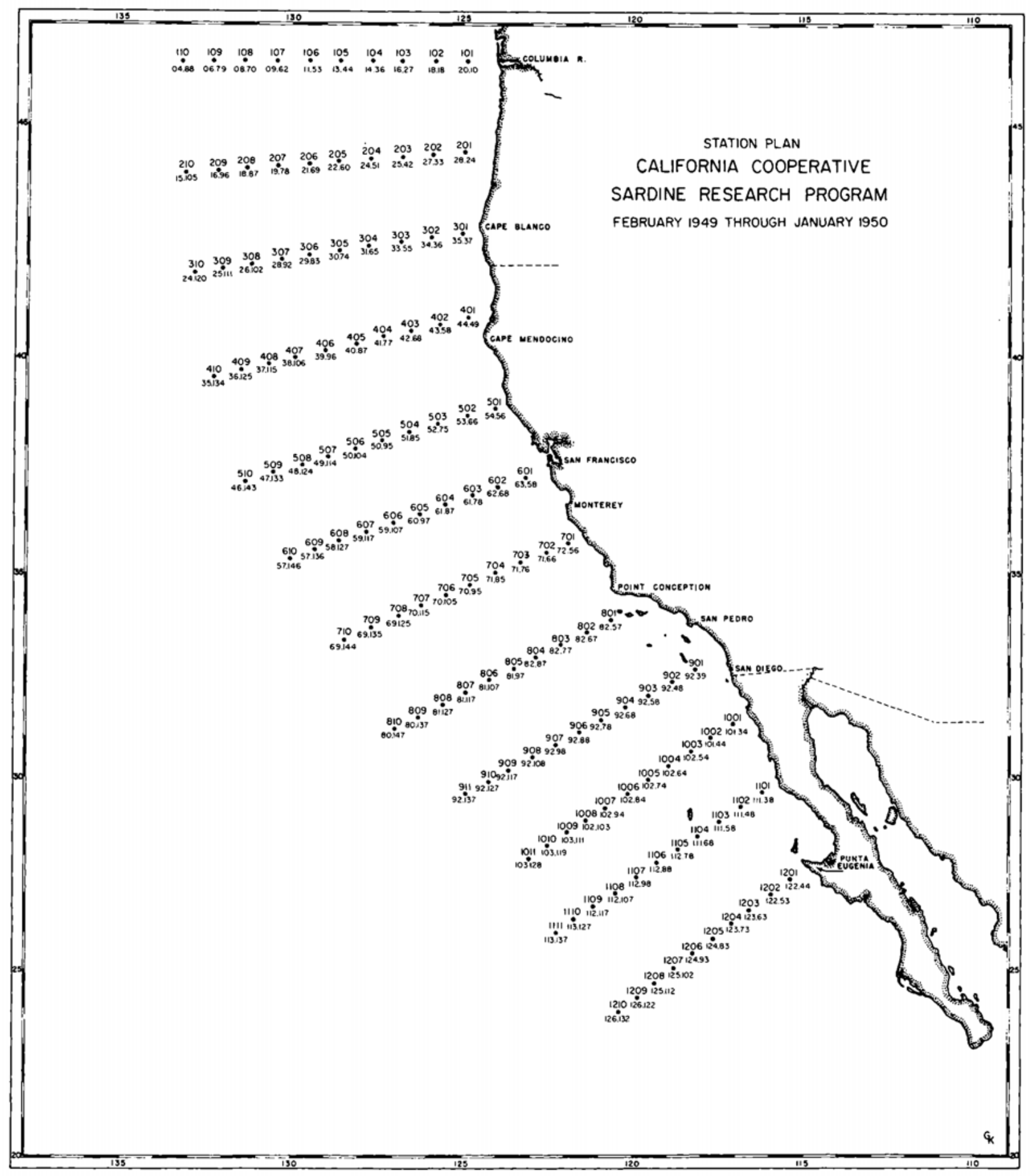

CHART 35. Station plan of the California Cooperative Oceanic Fisheries Investigations (formerly California Cooperative Sardine Research Program) from February, 1949, to January, 1950, inclusive. with equivalent numbers according to present station numbering system 
